\title{
Reactions of an Aromatic $\sigma, \sigma$-Biradical with Amino Acids and Dipeptides in the Gas Phase
}

\author{
Mingkun Fu, Sen Li, Enada Archibold, Michael J. Yurkovich, \\ John J. Nash, and Hilkka I. Kenttämaa \\ Department of Chemistry, Purdue University, West Lafayette, Indiana, USA
}

\begin{abstract}
Gas-phase reactivity of a positively charged aromatic $\sigma, \sigma$-biradical ( $N$-methyl-6,8-didehydroquinolinium) was examined toward six aliphatic amino acids and 15 dipeptides by using Fourier transform ion cyclotron resonance mass spectrometry (FT-ICR) and laser-induced acoustic desorption (LIAD). While previous studies have revealed that $\mathrm{H}$-atom and $\mathrm{NH}_{2}$ abstractions dominate the reactions of related monoradicals with aliphatic amino acids and small peptides, several additional, unprecedented reaction pathways were observed for the reactions of the biradical. For amino acids, these are $2 \mathrm{H}$-atom abstraction, $\mathrm{H}_{2} \mathrm{O}$ abstraction, addition $-\mathrm{CO}_{2}$, addition $-\mathrm{HCOOH}$, and formation of a stable adduct. The biradical reacts with aliphatic dipeptides similarly as with aliphatic amino acids, but undergoes also one additional reaction pathway, addition/C-terminal amino acid elimination (addition - $\mathrm{CO}-\mathrm{NHCHR}_{\mathrm{C}}$ ). These reactions are initiated by $\mathrm{H}$-atom abstraction by the biradical from the amino acid or peptide, or nucleophilic addition of an $\mathrm{NH}_{2}$ or a $\mathrm{HO}$ group of the amino acid or peptide at the radical site at C-6 in the biradical. Reactions of the unquenched C-8 radical site then yield the products not observed for related monoradicals. The biradical reacts with aromatic dipeptides with an aromatic ring in N-terminus (i.e., Tyr-Leu, Phe-Val, and Phe-Pro) similarly as with aliphatic dipeptides. However, for those aromatic dipeptides that contain an aromatic ring in the C-terminus (i.e., Leu-Tyr and Ala-Phe), one additional pathway, addition/ $\mathrm{N}$-terminal amino acid elimination (addition - $\mathrm{CO}-\mathrm{NHCHR}_{\mathrm{N}}$ ), was observed. This reaction is likely initiated by radical addition of the biradical at the aromatic ring in the $\mathrm{C}$-terminus. Related monoradicals add to aromatic amino acids and small peptides, which is followed by $\mathrm{C} \alpha-\mathrm{C} \beta$ bond cleavage, resulting in side-chain abstraction by the radical. For biradicals, with one unquenched radical site after the initial addition, the reaction ultimately results in the loss of the N-terminal amino acid. Similar to monoradicals, the C-S bond in amino acids and dipeptides was found to be especially susceptible to biradical attack. (J Am Soc Mass Spectrom 2010, 21, 1737-1752) (c) 2010 Published by Elsevier Inc. on behalf of American Society for Mass Spectrometry
\end{abstract}

$\mathrm{T}$ The damage induced by radicals to proteins has attracted great interest since these reactions are thought to play a major role in many oxidative processes, and they have been implicated in a number of human diseases as well as aging and inflammation [1-8]. Thus far, a variety of reactions of radicals with proteins have been discovered, including $\mathrm{H}$-atom abstraction, electron-transfer (leading to oxidation or reduction of the protein) and addition, which can cause fragmentation, rearrangement, dimerization, and disproportionation [1-13]. Most of this information has been obtained while examining reactions of simple oxygen-containing electrophilic radicals (i.e., hydroxyl and alkoxyl radicals) with amino acids, peptides, and proteins in the condensed phase [9-13]. The hydroxyl radical, for example, has been reported to abstract a $\mathrm{H}$-atom from the $\mathrm{C} \alpha$-position, from an alkyl group, and from an amino group of aliphatic amino acids in

Address reprint requests to Dr. H. I. Kenttämaa, Department of Chemistry, Purdue University, BRWN Building, 560 Oval Drive, West Lafayette, IN 47907, USA. E-mail: hilkka@purdue.edu aqueous solution [10, 11]. This radical has been also reported to add to the aromatic ring in aromatic amino acids and to the sulfur atoms in methionine and cysteine [6].

In sharp contrast to oxygen-containing radicals, only little effort has been directed towards understanding the reactions of carbon-centered organic radicals (e.g., phenyl radicals) with proteins or their components. In fact, we are aware of only one such solution study. This study revealed that the para-benzoic acid radical (4dehydrobenzoic acid) abstracts a D-atom from the $\alpha$ position of $\alpha, \alpha$-dideuterioglycine in solution [14]. It is not surprising, then, that protein damage caused by related biradicals is nearly entirely unexplored. This is true in spite of the fact that aromatic $\sigma, \sigma$-biradicals released in biological systems by some drugs, such as the enediyne antitumor antibiotics, have attracted a great deal of interest because of their efficiency in nonhydrolytic DNA damage [15-20]. The enediyne chromoproteins (e.g., kedarcidin and neocarzinostatin) and their apoproteins have been found to cause damage not only to DNA but also to proteins [21-23]. More
(C) 2010 Published by Elsevier Inc. on behalf of American Society for Mass Spectrometry. $1044-0305 / 10 / \$ 32.00$

doi:10.1016/j.jasms.2010.06.010
Published online June 25, 2010 Received May 5, 2009 Revised June 16, 2010 Accepted June 16, 2010 
notably, some synthetic enediynes have been reported to extensively damage proteins [24, 25]. In one of these studies, the synthetic enediyne was found to abstract a D-atom from the $\alpha \mathrm{C}$-position of deuterated glycine mimics, likely via a biradical intermediate (Scheme 1) [25].

All of the studies mentioned above were carried out in solution. The major advantage of liquid-phase studies is that many sophisticated analytical techniques can be employed, such as fast optical (and occasionally infrared) spectroscopy, conductivity measurements, electron paramagnetic (or spin) resonance (EPR or ESR) spectroscopy, and nuclear magnetic resonance (NMR) spectroscopy [26, 27]. However, liquid-phase studies of the reactions of carbon-centered mono- and biradicals are challenging due to undesirable side reactions with the solvent and impurities, and the difficulty in generating pure carbon-centered (bi)radicals in solution.

Gas-phase experiments provide a way to examine the intrinsic chemical properties of highly reactive mono- and biradicals in a solvent-free environment. For example, the homolytic $\mathrm{C}-\mathrm{H}$ bond dissociation energy of benzyne and the heats of formation of the ortho-, meta- and para-benzynes were measured by using gasphase techniques [28, 29]. Further, gas-phase studies on phenyl radicals have revealed reactivity toward protein components that is quite similar to that observed for 4-dehydrobenzoic acid in solution [14, 30-33]. For example, the gaseous 5-dehydro-2-(2-hydroxymethyl-18-crown6)naphthoate radical has been reported to abstract a $\mathrm{H}$-atom from the $\alpha \mathrm{C}$-position or from an alkyl side chain of peptides while noncovalently attached to the peptides [30]. Gas-phase ion-molecule reactions have been also employed to study reactions of phenyl radicals with amino acids by using Fourier-transform ion cyclotron resonance (FT-ICR) mass spectrometry and the distonic ion approach [31, 32] (i.e., by affixing a charged moiety to the radical of interest to permit its mass spectrometric manipulation and analysis). Later, the gas-phase reactivity of selected positively charged phenyl radicals toward small peptides was examined by using the laser-induced acoustic desorption [33]
(LIAD) technique, which allows the evaporation of nonvolatile neutral intact molecules (e.g., peptides, dinucleoside phosphates, and petroleum) with low internal and kinetic energies into the FT-ICR [34-38]. These gasphase studies, carried out on positively charged phenyl radicals, have revealed reactivity that is similar to that observed for neutral hydroxyl and phenyl radicals in solution. For example, both a condensed-phase neutral phenyl radical (the 4-dehydrobenzoic acid) and gaseous positively charged phenyl radicals [e.g., N-(3dehydrophenyl)pyridinium] rapidly abstract a D-atom from the $\alpha \mathrm{C}$-position of $\alpha, \alpha$-dideuterioglycine [14, 31]. Further, positively charged gaseous phenyl radicals [e.g., $N$-(3-dehydrophenyl)pyridinium] react with other aliphatic amino acids via the expected $\mathrm{H}$-atom abstraction from the $C \alpha$-position or an alkyl side chain, just as reported for the hydroxyl radical in solution (see above) $[10,31]$. Furthermore, addition to the aromatic ring is the major pathway of the hydroxyl radical upon reaction with aromatic amino acids in the condensed phase, just as observed for positively charged phenyl radicals (e.g., 3-dehydropyridinium) in the gas phase [32]. However, these gas-phase adducts often undergo a homolytic $\mathrm{C} \alpha-\mathrm{C} \beta$ bond cleavage [32], which has not been reported for the condensed-phase adducts. The $\mathrm{C} \alpha-\mathrm{C} \beta$ bond cleavage is likely caused by the solvation energy provided to the collision complex by the amino acid, which cannot be removed from the adduct by solvent in the gas phase. Finally, the condensed-phase hydroxyl radical has been reported to add to the sulfur atoms in methionine and cysteine [6], just like positively charged phenyl radicals in the gas phase. However, again, the adducts of the gas-phase phenyl radicals dissociate to yield $\mathrm{SCH}_{3}$ or $\mathrm{SH}$ abstraction products [31].

Encouraged by the above findings, we decided to explore the gas-phase reactivity of carbon-centered aromatic biradicals with protein components. Herein, we report on the reactivity of the $N$-methyl-6,8didehydroquinolinium biradical (Scheme 2) toward six amino acids and 15 dipeptides. This particular biradical was selected for this study due to its high and radical-

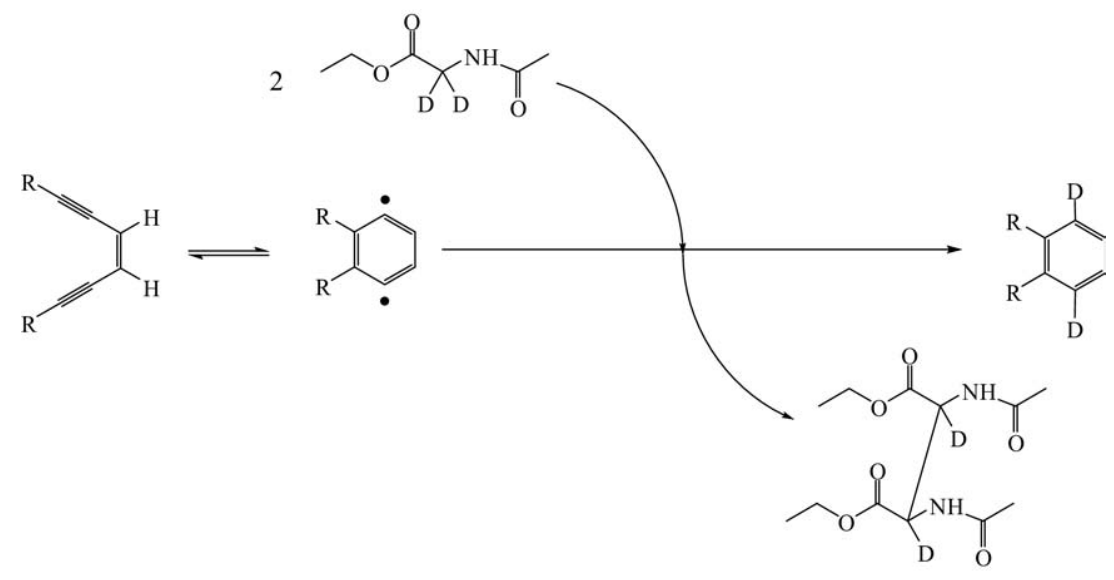

Scheme 1 


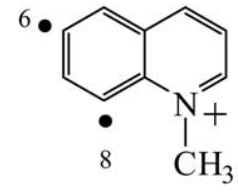

Scheme 2

like reactivity [39-43]. The observed reactivity is compared with that of related monoradicals, as well as the hydroxyl radical.

\section{Experimental}

Reactions of six amino acids (Table 1 ) and 15 dipeptides (Table 2) with the aromatic $\sigma, \sigma$-biradical, $N$-methyl-6,8didehydroquinolinium (Scheme 2), were examined in a 3 Tesla Nicolet model FTMS 2000 dual-cell FT-ICR mass spectrometer equipped with an Odyssey data acquisition system, as described previously [44, 45]. The particular biradical selected for this study can be generated in high abundance by using procedures reported [39, 40] previously, which makes it ideal for the very challenging experiments described here. To avoid the possibility of proton transfer reactions (i.e., the proton transfer pathway dominates the reaction of the protonated monoradical 3-dehydropyridinium with valine, proline, cysteine, and methionine [31]), the biradical was $\mathrm{N}$-methylated in this study.

The biradical's precursor ion was generated via $\mathrm{CH}_{3} \mathrm{I}$ chemical ionization of 6,8-dinitroisoquinoline, as described previously [39]. 6,8-Dinitroisoquinoline was synthesized by using known methods [39, 46-48]. 6,8Dinitroisoquinoline was introduced into one side of the dual cell via a solids probe at a nominal pressure of $1.0-5.0 \times 10^{-8}$ Torr. After ionization, the $\mathrm{N}$-methylated precursor ion was transferred into the other cell by grounding the conductance limit plate for about $154 \mu \mathrm{s}$. The quadrupolar axialization [49] (QA) technique was employed to enhance the ion transfer efficiency. After transfer, the biradical was generated by homolytic cleavages of the two carbon-nitrogen bonds by using sustained off-resonance irradiation collision-activated dissociation [50] (SORI-CAD). This was accomplished by introducing argon (at a nominal pressure of about $10^{-5}$ torr) into the cell via a pulsed valve assembly, and by kinetically exciting the precursor ions for $0.3 \mathrm{~s}$ by using an rf-field with a frequency $1 \mathrm{kHz}$ higher than the ions' cyclotron frequency. Collisions of the accelerated ions with argon result in cleavage of the two nitro groups. The biradical ions were then isolated by applying a series of stored-waveform inverse Fourier transform (SWIFT) [51, 52] excitation pulses to eject unwanted ions from the cell. The biradical ions were then allowed to react with amino acids and peptides evaporated into the mass spectrometer by using LIAD. It should be noted here that we have examined many related ortho-benzynes, and their chemical properties differ drastically from those of the ion studied here.
Table 1. Reactions (and their branching ratios ${ }^{\mathrm{a}}$ ) of the biradical with amino acids

\begin{tabular}{|c|c|}
\hline Amino acids & Reactions (branching ratio) \\
\hline $\begin{array}{l}\text { Gly } \\
\mathrm{NH}_{2}-\mathrm{CH}_{2}-\stackrel{\mathrm{O}}{\mathrm{C}}-\mathrm{OH}\end{array}$ & $\begin{array}{l}\mathrm{H} \text {-atom abstraction }(4 \%) \\
2 \mathrm{H} \text {-atom abstraction }(9 \%) \\
\mathrm{NH}_{2} \text { abstraction }(3 \%) \\
\mathrm{H}_{2} \mathrm{O} \text { abstraction }(17 \%) \\
\text { Addition- } \mathrm{HCOOH}(18 \%) \\
\text { Addition- } \mathrm{CO}_{2}(27 \%) \\
\text { Addition }(18 \%) \\
\text { Formation of } \mathrm{C}_{9} \mathrm{H}_{8} \mathrm{~N}^{+}(4 \%) \\
\text { Proton transfer (protonated Gly) }\end{array}$ \\
\hline 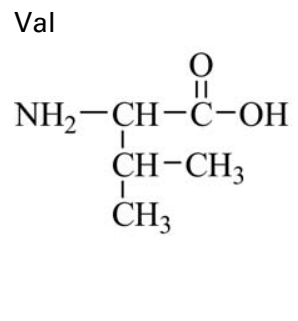 & $\begin{array}{l}\mathrm{H} \text {-atom abstraction }(6 \%) \\
2 \mathrm{H} \text {-atom abstraction }(11 \%) \\
\mathrm{NH}_{2} \text { abstraction }(5 \%) \\
\mathrm{H}_{2} \mathrm{O} \text { abstraction }(27 \%) \\
\text { Addition- } \mathrm{HCOOH}(24 \%) \\
\text { Addition- } \mathrm{CO}_{2}(12 \%) \\
\text { Addition }(12 \%) \\
\text { Formation of } \mathrm{C}_{9} \mathrm{H}_{8} \mathrm{~N}^{+}(3 \%) \\
\text { Proton transfer (protonated } \mathrm{Va})^{\mathrm{b}}\end{array}$ \\
\hline
\end{tabular}

Ile<smiles>CCC(C)C(N)C(=O)O</smiles>

$\mathrm{H}$-atom abstraction (3\%)

$2 \mathrm{H}$-atom abstraction (9\%)

$\mathrm{NH}_{2}$ abstraction (2\%)

$\mathrm{H}_{2} \mathrm{O}$ abstraction (35\%)

Addition- $\mathrm{HCOOH}(28 \%)$

Addition- $\mathrm{CO}_{2}(11 \%)$

Addition (11\%)

Formation of $\mathrm{C}_{9} \mathrm{H}_{8} \mathrm{~N}^{+}(1 \%)$

Proton transfer (protonated Ile) $)^{\mathrm{b}}$<smiles>O=C(O)C1CCCN1</smiles>

$\mathrm{H}$-atom abstraction (4\%)

$2 \mathrm{H}$-atom abstraction (10\%)

$\mathrm{H}_{2} \mathrm{O}$ abstraction (38\%)

Addition- $\mathrm{HCOOH}(27 \%)$

Addition- $-\mathrm{CO}_{2}(9 \%)$

Addition (5\%)

Formation of $\mathrm{C}_{9} \mathrm{H}_{8} \mathrm{~N}^{+}(7 \%)$

Proton transfer (protonated Pro) ${ }^{\mathrm{b}}$<smiles>CSCC(N)C(=O)O</smiles>

$\mathrm{H}$-atom abstraction (2\%)

$2 \mathrm{H}$-atom abstraction (4\%)

$\mathrm{H}_{2} \mathrm{O}$ abstraction (27\%)

$\mathrm{SCH}_{3}$ abstraction (15\%)

$\mathrm{HSCH}_{3}$ abstraction (39\%)

$\mathrm{SH}_{2}$ abstraction (3\%)

$\mathrm{SC}_{2} \mathrm{H}_{4}$ abstraction (6\%)

Addition (4\%)

Proton transfer (protonated Met) ${ }^{\mathrm{b}}$

Cys<smiles>NC(CS)C(=O)O</smiles>

$\mathrm{H}$-atom abstraction (8\%)

$2 \mathrm{H}$-atom abstraction (5\%)

$\mathrm{NH}_{2}$ abstraction (3\%)

$\mathrm{NH}_{3}$ abstraction (7\%)

$\mathrm{H}_{2} \mathrm{O}$ abstraction (15\%)

$\mathrm{S}$ abstraction (5\%)

$\mathrm{SH}$ abstraction (2\%)

$\mathrm{H}_{2} \mathrm{~S}$ abstraction (37\%)

Addition (3\%)

Formation of $\mathrm{C}_{9} \mathrm{H}_{8} \mathrm{~N}^{+}(18 \%)$

Proton transfer (protonated Cys) ${ }^{\mathrm{b}}$

aOnly primary reactions' branching ratios are listed.

${ }^{\mathrm{b}} \mathrm{A}$ slowly forming secondary product (protonated amino acid) was observed in all reactions, likely due to the high basicity of amino acids. 
Table 2. Reactions (branching ratio ${ }^{a}$ ) of the biradical with dipeptides

\begin{tabular}{|c|c|}
\hline Dipeptides & Reactions (branching ratio) \\
\hline $\mathrm{NH}_{2}-\mathrm{CH}_{2}-\stackrel{\mathrm{C}}{\|}-\mathrm{NH}-\mathrm{CH}_{2}-\stackrel{\mathrm{C}}{\|}-\mathrm{OH}$ & $\begin{array}{l}\mathrm{H} \text {-atom abstraction }(4 \%) \\
2 \mathrm{H} \text {-atom abstraction (3\%) } \\
\mathrm{H}_{2} \mathrm{O} \text { abstraction }(30 \%) \\
\text { Addition-CO- } \mathrm{NHCH}_{2}(31 \%) \\
\text { Addition-CO- } \mathrm{NHCH}_{2}-\mathrm{HCOOH}(11 \%) \\
\text { Addition- } \mathrm{CO}-\mathrm{NHCH}_{2}-\mathrm{H}_{2} \mathrm{O}(5 \%) \\
\text { Addition- } \mathrm{HCOOH}(5 \%) \\
\text { Addition- } \mathrm{CO}_{2}(4 \%) \\
\text { Addition }(7 \%) \\
\text { Proton transfer (protonated Gly-Gly) }\end{array}$ \\
\hline 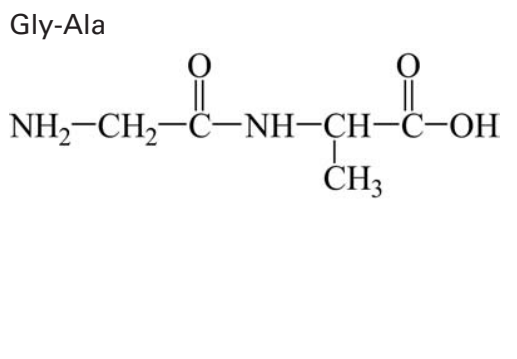 & $\begin{array}{l}\mathrm{H} \text {-atom abstraction (5\%) } \\
2 \mathrm{H} \text {-atom abstraction (3\%) } \\
\mathrm{H}_{2} \mathrm{O} \text { abstraction }(39 \%) \\
\text { Addition-CO- } \mathrm{NHCHCH} \mathrm{CH}_{3}(37 \%) \\
\text { Addition-CO- } \mathrm{NHCHCH}_{3}-\mathrm{CO}_{2}(2 \%) \\
\text { Addition-CO- } \mathrm{NHCHCH} \mathrm{CH}_{3}-\mathrm{H}_{2} \mathrm{O}(2 \%) \\
\text { Addition- } \mathrm{HCOOH}(5 \%) \\
\text { Addition- } \mathrm{CO}_{2}(2 \%) \\
\text { Addition }(5 \%) \\
\text { Proton transfer (protonated Gly-Ala) }\end{array}$ \\
\hline 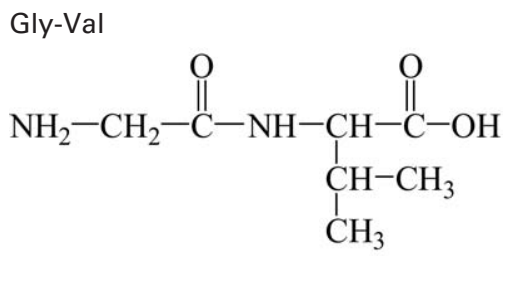 & $\begin{array}{l}\mathrm{H} \text {-atom abstraction }(7 \%) \\
2 \mathrm{H} \text {-atom abstraction }(3 \%) \\
\mathrm{H}_{2} \mathrm{O} \text { abstraction }(40 \%) \\
\text { Addition- } \mathrm{CO}-\mathrm{NHCHCH}\left(\mathrm{CH}_{3}\right)_{2}(37 \%) \\
\text { Addition- } \mathrm{CO}-\mathrm{NHCHCH}\left(\mathrm{CH}_{3}\right)_{2}-\mathrm{HCOOH}(3 \%) \\
\text { Addition- } \mathrm{HCOOH}(6 \%) \\
\text { Addition }(4 \%) \\
\text { Proton transfer (protonated Gly-Val) }\end{array}$ \\
\hline 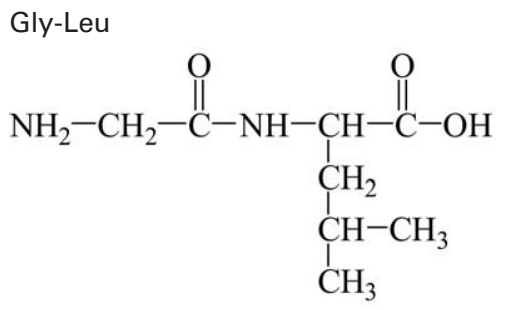 & $\begin{array}{l}\mathrm{H} \text {-atom abstraction }(9 \%) \\
2 \mathrm{H} \text {-atom abstraction }(4 \%) \\
\mathrm{H}_{2} \mathrm{O} \text { abstraction }(41 \%) \\
\text { Addition-CO-NHCHCH}{ }_{2} \mathrm{CH}\left(\mathrm{CH}_{3}\right)_{2}(33 \%) \\
\text { Addition-CO-NHCHCH} \mathrm{CH}_{2} \mathrm{CH}\left(\mathrm{CH}_{3}\right)_{2}-\mathrm{HCOOH}(3 \%) \\
\text { Addition- } \mathrm{HCOOH}(3 \%) \\
\text { Addition }(7 \%) \\
\text { Proton transfer (protonated Gly-Leu) }\end{array}$ \\
\hline 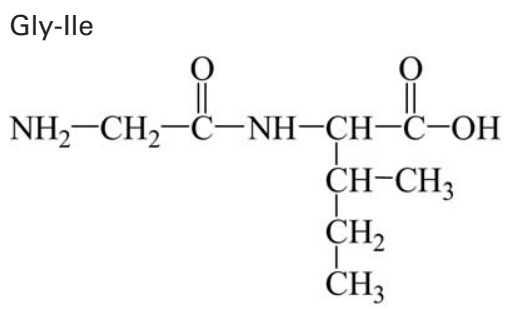 & $\begin{array}{l}\mathrm{H} \text {-atom abstraction }(9 \%) \\
2 \mathrm{H} \text {-atom abstraction }(4 \%) \\
\mathrm{H}_{2} \mathrm{O} \text { abstraction }(43 \%) \\
\text { Addition- } \mathrm{CO}-\mathrm{NHCHCH}\left(\mathrm{CH}_{3}\right) \mathrm{CH}_{2} \mathrm{CH}_{3}(35 \%) \\
\text { Addition- } \mathrm{HCOOH}(4 \%) \\
\text { Addition }(5 \%) \\
\text { Proton transfer (protonated Gly-lle) }\end{array}$ \\
\hline 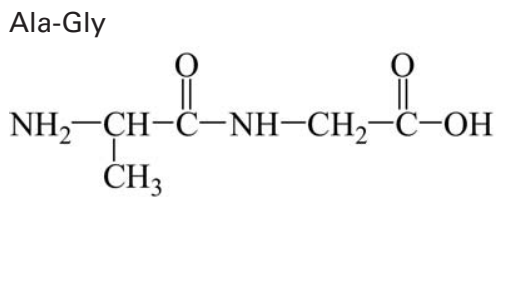 & $\begin{array}{l}\mathrm{H} \text {-atom abstraction }(8 \%) \\
2 \mathrm{H} \text {-atom abstraction }(6 \%) \\
\mathrm{H}_{2} \mathrm{O} \text { abstraction }(33 \%) \\
\text { Addition-CO- } \mathrm{NHCH}_{2}(28 \%) \\
\text { Addition-CO- } \mathrm{NHCH}_{2}-\mathrm{CO}_{2}(12 \%) \\
\text { Addition- } \mathrm{CO}_{2}(6 \%) \\
\text { Addition }(7 \%) \\
\text { Proton transfer (protonated Ala-Gly) }\end{array}$ \\
\hline
\end{tabular}


Table 2. Continued<smiles>CC(C)CC(NC(=O)C(N)Cc1ccc(O)cc1)C(=O)O</smiles>

Phe-Val<smiles>CC(C)C(NC(=O)C(N)Cc1ccccc1)C(=O)O</smiles>

Phe-Pro<smiles>NC(Cc1ccccc1)C(=O)N1CCCC1C(=O)O</smiles>

Ala-Phe<smiles>CC(N)C(=O)NC(Cc1ccccc1)C(=O)O</smiles>

Leu-Tyr<smiles>CC(C)CC(N)C(=O)NC(Cc1ccc(O)cc1)C(=O)O</smiles>

Cys-Gly<smiles>NC(CS)C(=O)NCC(=O)O</smiles>

Reactions (branching ratio)

$\mathrm{H}$-atom abstraction (6\%)

$2 \mathrm{H}$-atom abstraction (3\%)

$\mathrm{H}_{2} \mathrm{O}$ abstraction (27\%)

Addition-CO-NHCHCH${ }_{2} \mathrm{CH}\left(\mathrm{CH}_{3}\right)_{2}$ (37\%)

Addition-CO-NHCHCH${ }_{2} \mathrm{C}_{3} \mathrm{H}_{7}-\mathrm{HCOOH}(5 \%)$

Addition- $-\mathrm{CO}_{2}(6 \%)$

Addition (10\%)

Unknown (m/z 226) (3\%)

Unknown (m/z 249) (3\%)

Proton transfer (protonated Try-Leu) ${ }^{\mathrm{b}}$

$\mathrm{H}$-atom abstraction (5\%)

$2 \mathrm{H}$-atom abstraction (3\%)

$\mathrm{H}_{2} \mathrm{O}$ abstraction (42\%)

Addition-CO-NHCHCH$\left(\mathrm{CH}_{3}\right)_{2}$ (36\%)

Addition- $\mathrm{CO}_{2}(3 \%)$

Addition (11\%)

Proton transfer (protonated Phe-Val) ${ }^{\mathrm{b}}$

$\mathrm{H}$-atom abstraction (4\%)

$\mathrm{H}_{2} \mathrm{O}$ abstraction (25\%)

Addition-CO- $\mathrm{C}_{4} \mathrm{H}_{6} \mathrm{~N}$ (39\%)

Addition- $\mathrm{CO}-\mathrm{C}_{4} \mathrm{H}_{6} \mathrm{~N}-\mathrm{HCOOH}(9 \%)$

Addition- $\mathrm{CO}_{2}(6 \%)$

Addition (7\%)

Unknown (m/z 291) (10\%)

Proton transfer (protonated Phe-Pro) ${ }^{\mathrm{b}}$

$\mathrm{H}$-atom abstraction (3\%)

$2 \mathrm{H}$-atom abstraction (3\%)

$\mathrm{H}_{2} \mathrm{O}$ abstraction (44\%)

Addition-CO-NHCHCH${ }_{2} \mathrm{C}_{6} \mathrm{H}_{5}$ (30\%)

Addition-CO-NHCHCH (8\%)

Addition- $\mathrm{CO}_{2}$ (7\%)

Addition (5\%)

Proton transfer (protonated Ala-Phe) ${ }^{\mathrm{b}}$

$\mathrm{H}$-atom abstraction (5\%)

$2 \mathrm{H}$-atom abstraction (3\%)

$\mathrm{H}_{2} \mathrm{O}$ abstraction (34\%)

Addition-CO-NHCHCH${ }_{2} \mathrm{C}_{6} \mathrm{H}_{4} \mathrm{OH}$ (18\%)

Addition-CO- $\mathrm{NHCHCH}_{2} \mathrm{CH}_{2}\left(\mathrm{CH}_{3}\right)_{2}(11 \%)$

Addition-CO-NHCHCH $\mathrm{C}_{6} \mathrm{H}_{4} \mathrm{OH}-\mathrm{HCOOH}(2 \%)$

Addition- $\mathrm{CO}_{2}$ (8\%)

Addition (17\%)

Unknown ( $\mathrm{m} / \mathrm{z} 401)(2 \%)$

Proton transfer (protonated Leu-Try) ${ }^{\mathrm{b}}$

$\mathrm{H}$-atom-atom abstraction (7\%)

$2 \mathrm{H}$-atom abstraction (3\%)

$\mathrm{H}_{2} \mathrm{O}$ abstraction (10\%)

$\mathrm{H}_{2} \mathrm{~S}$ abstraction (61\%)

Addition-CO- $\mathrm{NHCH}_{2}$ (12\%)

Addition- $\mathrm{HCOOH}$ (274) (2\%)

Addition (5\%)

Proton transfer (protonated Cys-Gly) ${ }^{\mathrm{b}}$

(Continued) 
Table 2. Continued

\begin{tabular}{|c|c|}
\hline Dipeptides & Reactions (branching ratio) \\
\hline 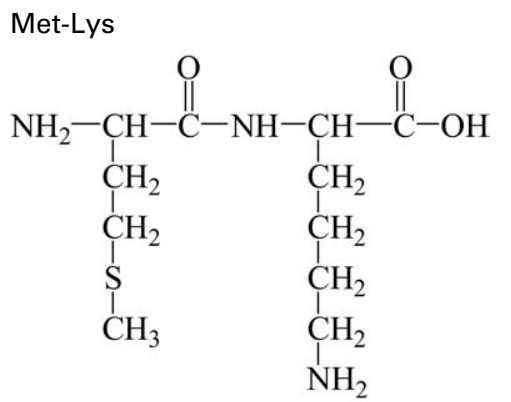 & $\begin{array}{l}\mathrm{H}_{2} \mathrm{O} \text { abstraction (13\%) } \\
\mathrm{SCH}_{3} \text { abstraction }(10 \%) \\
\mathrm{HSCH}_{3} \text { abstraction }(54 \%) \\
\text { Addition-CO- } \mathrm{NHCH}\left(\mathrm{CH}_{2}\right)_{4} \mathrm{NH}_{2}(7 \%) \\
\text { Addition-CO-NHCH}\left(\mathrm{CH}_{2}\right)_{2} \mathrm{SCH}_{3}(10 \%) \\
\text { Addition }(6 \%) \\
\text { Proton transfer (protonated Met-Lys) }\end{array}$ \\
\hline 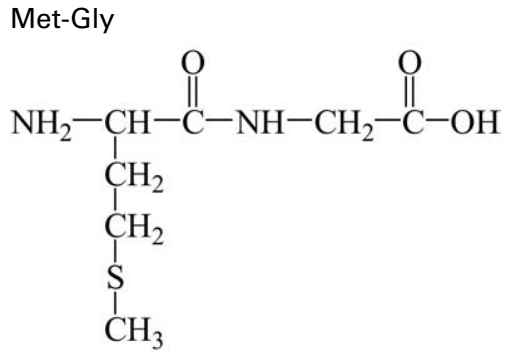 & $\begin{array}{l}\mathrm{H} \text {-atom abstraction (2\%) } \\
2 \mathrm{H} \text {-atom abstraction (1\%) } \\
\mathrm{H}_{2} \mathrm{O} \text { abstraction (12\%) } \\
\mathrm{SCH}_{3} \text { abstraction (15\%) } \\
\mathrm{HSCH}_{3} \text { abstraction }(54 \%) \\
\mathrm{SH}_{2} \text { abstraction }(5 \%) \\
\mathrm{SC}_{2} \mathrm{H}_{4} \text { abstraction }(5 \%) \\
\mathrm{Addition} \mathrm{CO}-\mathrm{NHCH}_{2}(4 \%) \\
\text { Addition }(2 \%) \\
\text { Proton transfer (protonated Met-Gly) }\end{array}$ \\
\hline Val-Met $\stackrel{\stackrel{\mathrm{O}}{\mathrm{O}}}{\mathrm{NH}}-\stackrel{\mathrm{C}}{\mathrm{C}}-\stackrel{\mathrm{C}}{\mathrm{C}}-\mathrm{NH}-\underset{\mathrm{C}}{\mathrm{C}} \mathrm{H}-\stackrel{\mathrm{C}}{\mathrm{C}}-\stackrel{\mathrm{C}}{\mathrm{C}}-\mathrm{OH}$ & $\begin{array}{l}\mathrm{H} \text {-atom abstraction (2\%) } \\
\mathrm{H}_{2} \mathrm{O} \text { abstraction (8\%) } \\
\mathrm{SCH}_{3} \text { abstraction (9\%) } \\
\mathrm{HSCH}_{3} \text { abstraction }(69 \%) \\
\mathrm{SC}_{2} \mathrm{H}_{3} \text { abstraction }(7 \%) \\
\text { Addition-CO-NHCH}\left(\mathrm{CH}_{2}\right)_{2} \mathrm{SCH}_{3}(5 \%) \\
\text { Proton transfer (protonated } \mathrm{Val}-\mathrm{Met})^{\mathrm{b}}\end{array}$ \\
\hline
\end{tabular}

aOnly primary products' branching ratios are listed.

${ }^{b}$ A slowly formed secondary product (protonated dipeptide) was observed in all reactions, likely due to the high basicity of the dipeptides.

Hence, isomerization of the meta-benzyne to a more stable ortho-benzyne can be ruled out.

Amino acids and dipeptides were dissolved in methanol ( $\sim 1 \mathrm{mM})$ and electrospray-deposited onto $12.7 \mu \mathrm{m}$ thick titanium foils $\left(\sim 150 \mathrm{nmol} / \mathrm{cm}^{2}\right)$, as described previously [33]. The foil was mounted onto a manual insertion LIAD probe equipped with an optical fiber $[35,39,40,53]$, which was inserted into the mass spectrometer. The amino acid and peptide molecules were evaporated into the cell by using 30-300 laser shots (Continuum Minilite Nd:YAG laser, Santa Clara, CA, USA, light of 532-nm wavelength, 3-ns pulse width, $10-\mathrm{Hz}$ repetition rate) applied in a circular pattern on the backside of a Ti foil (the side opposite to where the sample was deposited). While the laser was fired, the LIAD probe was continuously rotated so that each laser pulse irradiated a fresh spot on the Ti foil. Each laser shot desorbed molecules from an area of about $10^{-3} \mathrm{~cm}^{2}$ on the Ti foil (laser power density at the metal surface was $\sim 3 \times 10^{9} \mathrm{~W} / \mathrm{cm}^{2}$ ). Approximately $5 \%$ of the foil's total surface area was irradiated when the foil was rotated $360^{\circ}$. The desorbed amino acid or dipeptide molecules (with low kinetic and internal energies [33] were allowed to react with the charged biradicals. After reactions, all ions were excited for detection by using chirp excitation with a bandwidth of $2.7 \mathrm{MHz}$, and a sweep rate of $3200 \mathrm{~Hz} / \mu \mathrm{s}$. The spectra were recorded as $64 \mathrm{k}$ data points and subjected to Hanning apodization and one zero-fill before Fourier transformation. All spectra were corrected by subtraction of a background spectrum recorded by removing the reactant ion by SWIFT ejection before reaction to make sure that the observed product ions were generated by the desired ion population.

\section{Results and Discussion}

Previous studies [39, 40] have demonstrated that the aromatic $\sigma, \sigma$-biradical selected for this study, the $\mathrm{N}$-methyl-6,8-didehydroquinolinium, reacts with simple organic molecules mostly via radical (as opposed to electrophilic) pathways. This is true in spite of its a large singlet-triplet gap [40] $(-16.3 \mathrm{kcal} / \mathrm{mol})$, which hinders the radical reactivity of many other meta-benzyne type biradicals [41-43]. The critical reactivity-controlling parameter is the large dehydrocarbon atom separation of this particular biradical, which has been reported to facilitate radical-type reactions of meta-benzyne analogs $[40,43]$. 

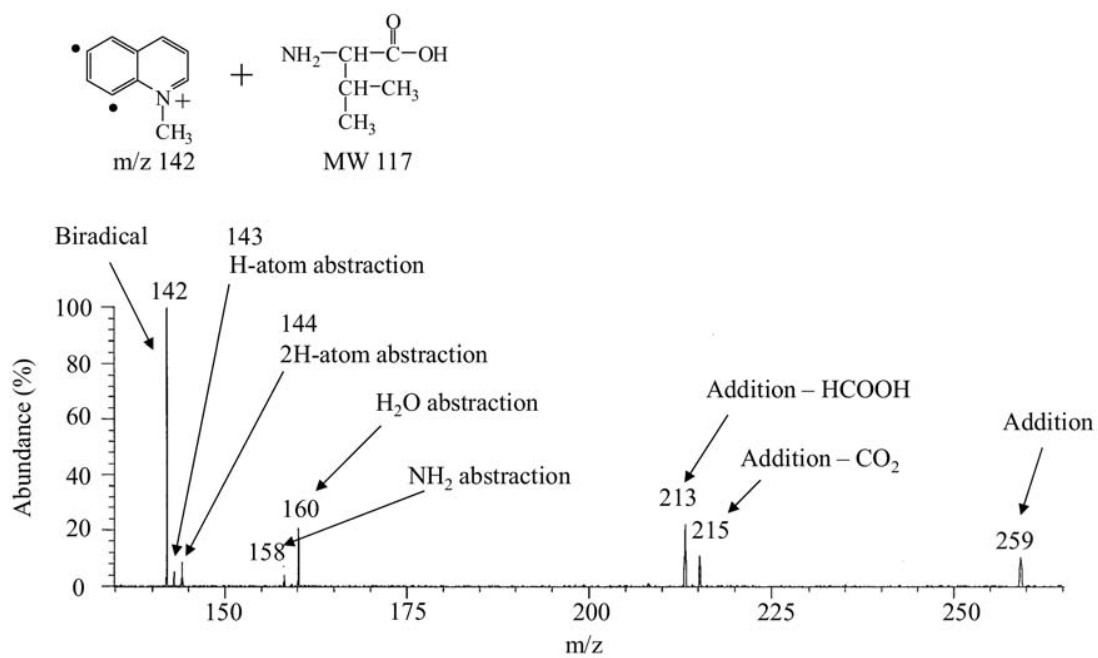

Figure 1. A mass spectrum measured for the reaction of the biradical $(m / z$ 142) with Val (MW 117) in FT-ICR.

\section{Amino Acids}

Amino acids can be separated into three categories based on the types of reactions they undergo with the biradical (Table 1). The first category contains the simplest aliphatic amino acids studied, Gly, Val, and Ile, the second contains Pro, and the third contains the sulfur-containing amino acids Cys and Met. These three categories are discussed in detail below.

\section{Gly, Val, and Ile}

While phenyl monoradicals react with the simplest amino acids exclusively by $\mathrm{H}$-atom and $\mathrm{NH}_{2}$ abstraction [31], the biradical reacts by several additional pathways. These include $2 \mathrm{H}$-atom abstraction, $\mathrm{H}_{2} \mathrm{O}$ abstraction, addition $-\mathrm{HCOOH}$, addition $-\mathrm{CO}_{2}$, as well as formation of a stable adduct (Table 1) (see Figure 1 for an example). Since the charged monoradicals predominantly attack these amino acids at $\mathrm{H}$ atoms and the amino group, these sites are also likely to be first attacked by the biradical studied here. Indeed, previous studies of the reactions of similar monoradicals and biradicals with DNA components suggest that the biradicals' reactions are initiated in the same manner as the monoradicals' reactions [35, 39, 40]. Hence, it is reasonable to propose that the biradicals' unprecedented reaction pathways start with either $\mathrm{H}$-atom abstraction or amino abstraction, and are followed by other reactions. The biradical's unique reaction pathways are discussed in detail next.

\section{H-Atom Abstraction}

Abstraction of $2 \mathrm{H}$-atoms must occur in a consecutive manner due to the distance between the radical sites. This reaction is likely initiated by $\mathrm{H}$-atom abstraction from $\alpha \mathrm{C}$ or from the alkyl chain of the amino acid. Plenty of evidence supports the vulnerability of the $\alpha \mathrm{C}-\mathrm{H}$ site of amino acids for radical attack. For example, para-benzoic acid radical (4-dehydrobenzoic acid) has been reported to abstract a D-atom from $\alpha \mathrm{C}$ of $\alpha, \alpha$-dideuterioglycine [14] and hydroxyl radical is known to abstract a $\mathrm{H}$-atom from $\alpha \mathrm{C}$ of aliphatic amino acids [6] in the condensed phase. Furthermore, synthetic enediynes have been demonstrated to abstract a D-atom from $\alpha \mathrm{C}$ of deuterated glycine mimics (Scheme 1) in solution [25]. It also has been reported that the homolytic $\alpha \mathrm{C}-\mathrm{H}$ bond dissociation energy in glycine $(79.2$ $\mathrm{kcal} / \mathrm{mol})$ is substantially lower than that of the $\mathrm{N}-\mathrm{H}$ (102.6 kcal/mol) and O-H bonds (112.9 kcal/mol) [54]. In addition to $\alpha \mathrm{C}$, the alkyl side-chain of aliphatic amino acids has been found to be another vulnerable site for phenyl radical attack. For example, for a given positively charged phenyl monoradical, the larger the alkyl side chain of the amino acid, the higher the branching ratio of $\mathrm{H}$-atom abstraction (gly $<$ ala $<$ val) [31]. This was also found to be true for oligopeptides (for example, the $\mathrm{H}$-atom branching ratio increases in the order gly-gly $<$ gly-ala $<$ gly-val) [33].

Based on calculated (UBLYP/cc-pVDZ; using the CHELPG procedure) charges (Scheme 3 ), the radical site 6 is the more electrophilic radical site in the biradical, and hence likely to be the site that initiates the

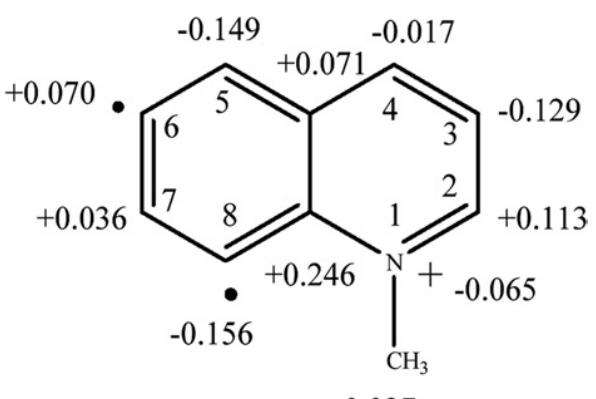

$-0.027$

Scheme 3 


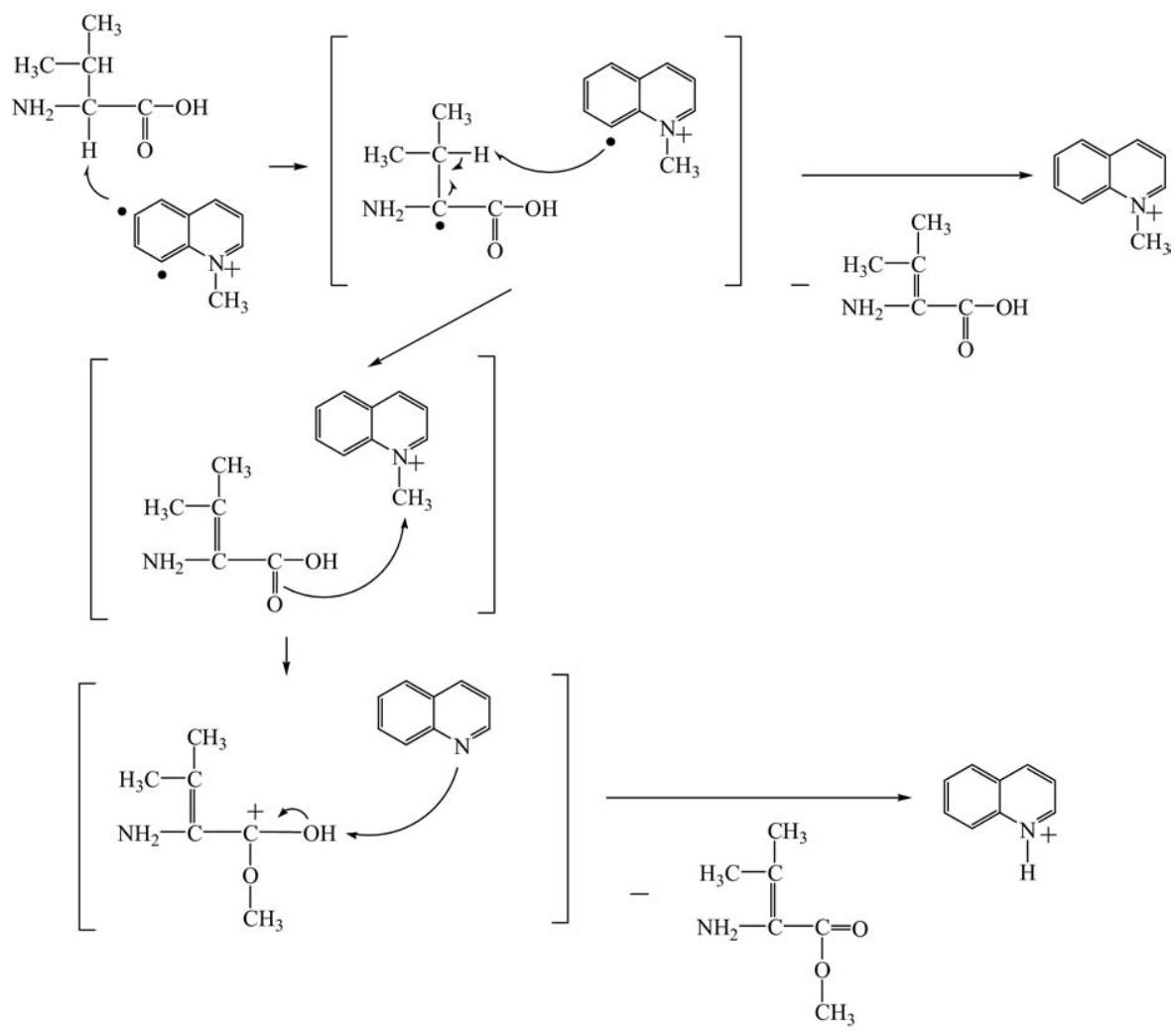

Scheme 4

reaction (for a proposed reaction mechanism for $\mathrm{H}$ atom abstraction from $\alpha \mathrm{C}$ of Val, see Scheme 4). Steric hindrance from the methyl group is also likely to direct the first reaction at the radical site on C-6.

After the first $\mathrm{H}$-atom abstraction, the unquenched radical site of the biradical likely abstracts another $\mathrm{H}$-atom from a carbon atom adjacent to the radical site in the amino acid radical (or its fragments) to generate a C-C double-bond (see Scheme 4 for an example). If the collision complex now dissociates, the $2 \mathrm{H}$-atom abstraction product is formed. On the other hand, if the $2 \mathrm{H}$-atom abstraction product transfers the methyl group to the dehydrogenated amino acid, followed by a proton transfer, the ion $\mathrm{C}_{9} \mathrm{H}_{8} \mathrm{~N}^{+}$is formed after dissociation of this new collision complex (see Scheme 4 for an example).

\section{Addition, Addition - $\mathrm{HCOOH}$, and Addition $-\mathrm{CO}_{2}$}

Possible mechanisms for the formation of the stable adduct and the addition $-\mathrm{HCOOH}$ and addition $-\mathrm{CO}_{2}$ products upon the reaction of the biradical with glycine are shown in Scheme 5 (the charge and odd spin distribution shown are based on earlier work [31] on related monoradicals). These reactions are likely initiated by nucleophilic addition of $\mathrm{NH}_{2}$ to the radical site at carbon 6 (calculated to be the most electron deficient radical site). Attack at carbon 6 rather than 8 is pro- posed based on transition-state calculations ((U)BLYP/ cc-pVDZ//(U)BLYP/cc-pVDZ level of theory). The activation enthalpies (relative to the separated reactants) calculated for the nucleophilic addition of ammonia to the 6- and 8-radical sites for 6,8-didehydroquinolinium ion are $-8.2 \mathrm{kcal} / \mathrm{mol}$ and $-3.6 \mathrm{kcal} / \mathrm{mol}$, respectively. Thus, addition to carbon 6 is kinetically favored, although addition to both sites may occur. As mentioned above, charged phenyl monoradicals [31] also abstract the amino group from amino acids, but their evenelectron analogs do not. Obviously, a radical site is needed for this reaction to occur.

Examination of the reactions of the biradical with simple organic compounds (e.g., hexylamine) suggests that the amino group is indeed highly susceptible to biradical attack. For example, the biradical reacts with hexylamine by $\mathrm{H}$-atom, $2 \mathrm{H}$-atom, $\mathrm{NH}_{2}$, and $\mathrm{NH}_{3}$ abstraction (likely $\mathrm{NH}_{2}$ abstraction followed by $\mathrm{H}$-atom abstraction), addition and formation of $\mathrm{C}_{9} \mathrm{H}_{8} \mathrm{~N}^{+}$. The dominating $\mathrm{NH}_{2}(49 \%)$ and $\mathrm{NH}_{3}$ abstractions (21\%) demonstrate that the amino group is the most susceptible site in hexylamine to the biradical attack.

For monoradicals, the nucleophilic addition of the amino group to the $\pi$-system at the dehydrocarbon is followed by a homolytic $\mathrm{NH}_{2}-\alpha \mathrm{C}$ cleavage [31]. The same was observed for the biradical. In this case, however, further reactions may take place before the product complex dissociates. In fact, $\mathrm{NH}_{2}$ abstraction is only a minor pathway for amino acids. More often, a 


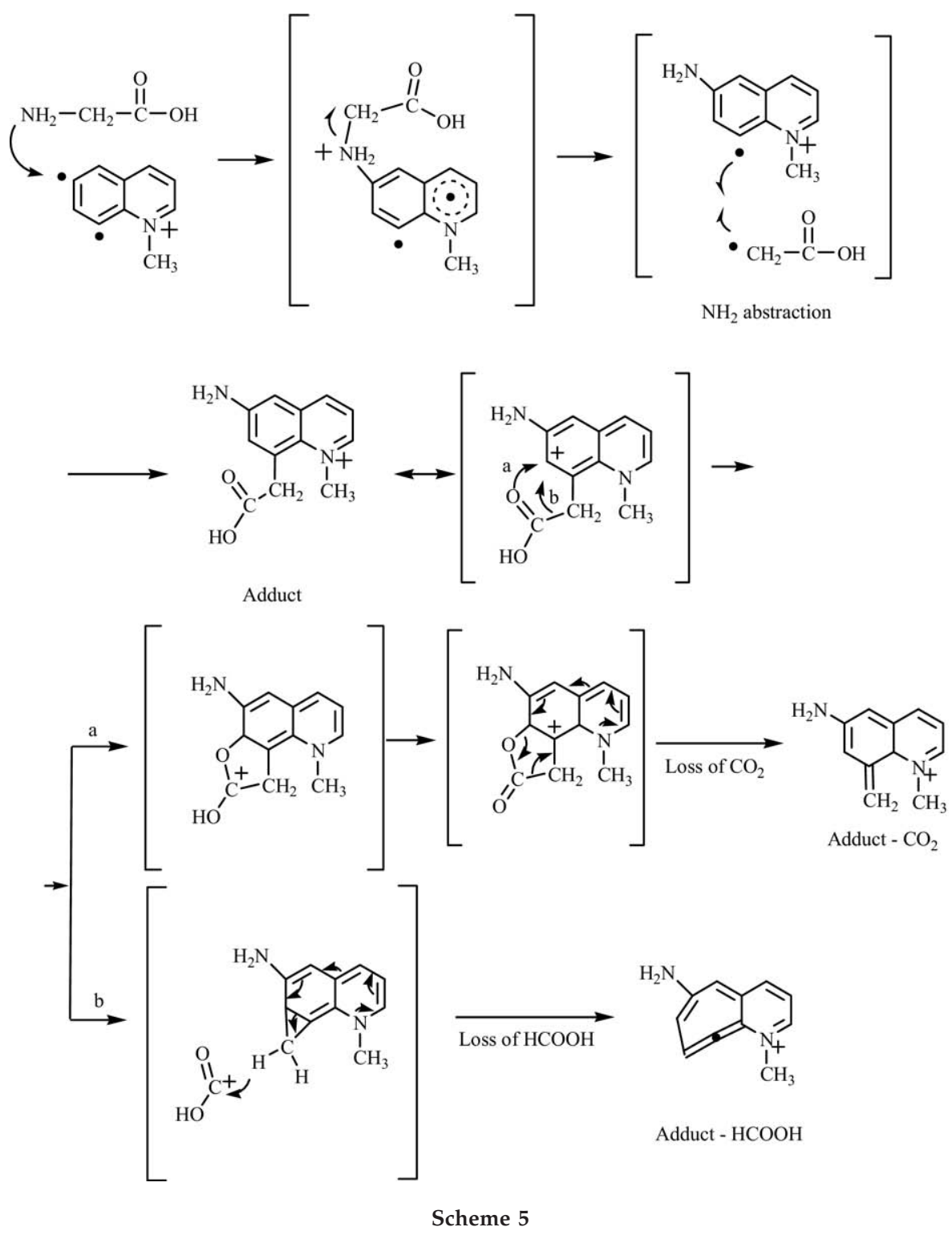

highly exothermic radical-radical recombination leads to a new, hot adduct that may either cool by emission of IR light to yield a stable adduct, or fragment by loss of $\mathrm{CO}_{2}$ or $\mathrm{HCOOH}$ (Scheme 5). Indeed, SORI-CAD of the stable adduct formed in the reaction of the biradical with Val was found to mainly involve loss of $\mathrm{CO}_{2}$ or $\mathrm{HCOOH}$.

\section{$\mathrm{H}_{2} \mathrm{O}$ Abstraction}

$\mathrm{H}_{2} \mathrm{O}$ abstraction by the biradical is facile for all the amino acids. A possible mechanism for $\mathrm{H}_{2} \mathrm{O}$ abstraction from glycine is shown in Scheme 6 . According to the transitionstate calculations ((U)BLYP/cc-pVDZ//(U)BLYP/cc-pVDZ level of theory) mentioned above, $\mathrm{H}_{2} \mathrm{O}$ abstraction is likely initiated by nucleophilic addition of $\mathrm{OH}$ to the radical site at carbon 6 in the same way as amino abstraction occurs (see Scheme 6).
To further probe the structure assigned to the $\mathrm{H}_{2} \mathrm{O}$ abstraction product, sustained off-resonance irradiation collision-activated dissociation (SORI-CAD) of the $\mathrm{H}_{2} \mathrm{O}$ abstraction product of the biradical with Val was examined. This product ion fragments by loss of CO. Since this fragmentation is not structurally informative without additional data, ions with the two most likely isomeric $\mathrm{H}_{2} \mathrm{O}$ abstraction product structures, $\mathrm{N}$-methyl-6- and $\mathrm{N}$ methyl-8-hydroxyquiniliniums, were independently generated in a linear quadrupole ion trap from commercial precursors by $\mathrm{CH}_{3} \mathrm{I}$ atmospheric pressure chemical ionization, and subjected to CAD. N-Methyl6-hydroxyquinolinium was found to fragment by loss of $\mathrm{CO}$, while $\mathrm{N}$-methyl-8-hydroxyquinolinium fragments via loss of $\mathrm{OH}$ and $\mathrm{CH}_{3}$. Hence, the $\mathrm{H}_{2} \mathrm{O}$ abstraction product of the biradical and $\mathrm{Val}$ is concluded to have the $N$-methyl-6-hydroxyquinolinium structure, and it is likely generated by addition of the 

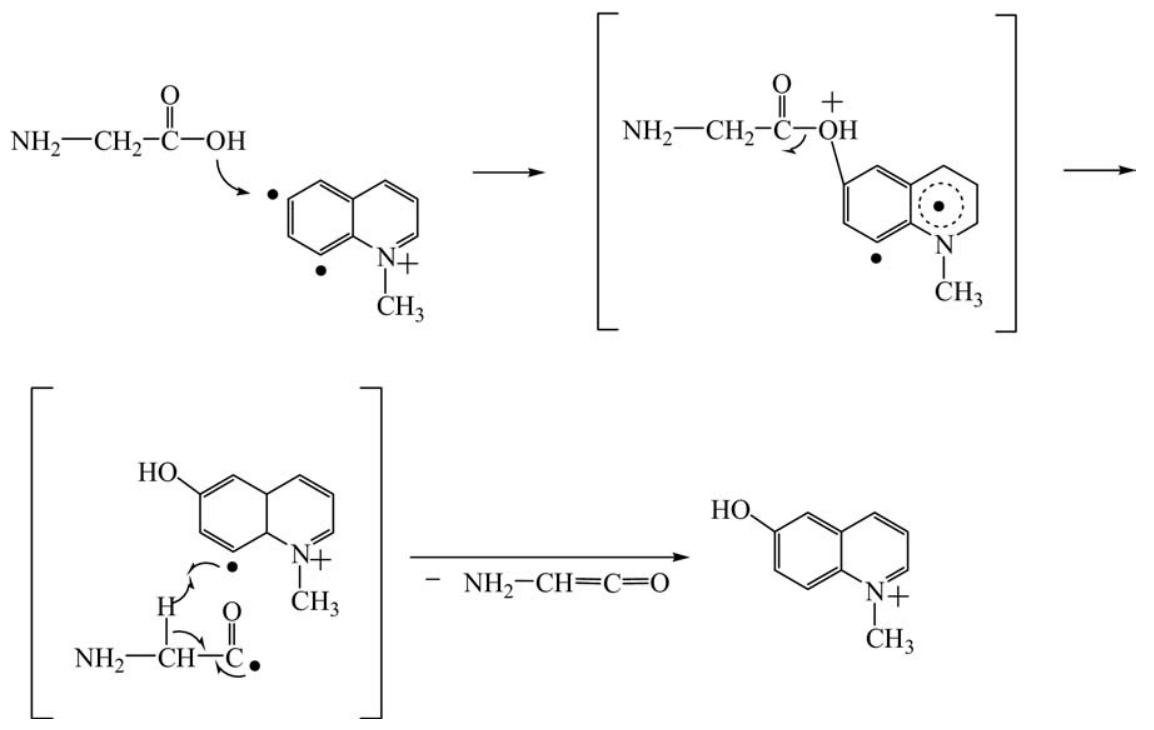

Scheme 6

HO-group at carbon-6, followed by $\mathrm{H}$ abstraction by the remaining radical site at carbon- 8 , in support of the mechanism shown in Scheme 6 .

\section{Proline}

Proline displays similar pathways upon reaction with the biradical as glycine, valine, and isoleucine, with one exception. No $\mathrm{NH}_{2}$ abstraction occurs in the reaction of proline with the biradical due to the absence of a terminal $\mathrm{NH}_{2}$ group. Instead, the biradical attacks the N-terminal $\mathrm{N}$-atom of proline, which is followed by ring-opening, resulting in a stable adduct and adduct $-\mathrm{HCOOH}$ and adduct $-\mathrm{CO}_{2}$ products. Earlier studies show that ringopening also occurs in the reactions of related monoradicals with a proline-containing dipeptide (Pro-Ala)
[33]. For example, $N$-phenyl-3-dehydropyridinium reacts with Pro-Ala via $\mathrm{NHCH}=\mathrm{CH}_{2}$ abstraction, $\mathrm{NHCH}_{2} \mathrm{CH}_{3}$ abstraction and $\mathrm{H}$-atom abstraction) [33]. A possible mechanism for addition - $\mathrm{HCOOH}$ and addition $-\mathrm{CO}_{2}$ is shown in Scheme 7 .

\section{Cys and Met}

Similar to monoradical attack [31], the S-C bond of S-containing amino acids (i.e., Cys and Met) was found to be especially vulnerable to biradical attack. However, while SR $\left(\mathrm{R}=\mathrm{H}\right.$ or $\left.\mathrm{CH}_{3}\right)$ abstraction dominates the reactions of monoradicals with S-containing amino acids, an additional reaction pathway, HSR abstraction, dominates the reactions of the biradical. For example, in addition to the $\mathrm{SCH}_{3}$ abstraction product, the biradical

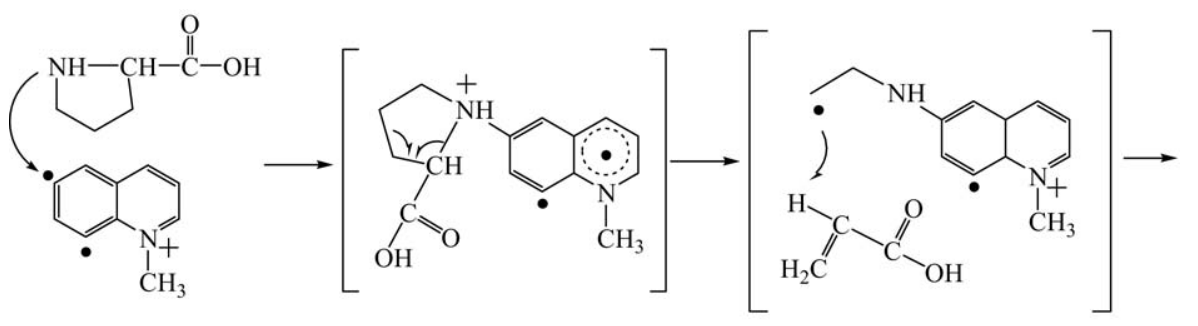<smiles>C=C(CCCc1cc(NCC)cc2ccc[n+](C)c12)C(=O)O</smiles>

Adduct 


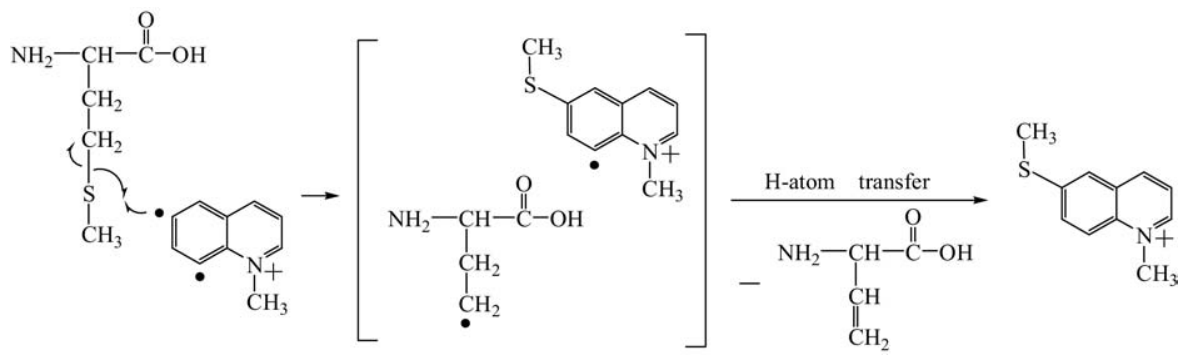

Scheme 8

reacts with Met by a predominant abstraction of $\mathrm{HSCH}_{3}$ (Table 1). The HSR abstraction is likely initiated by SR abstraction from the amino acid molecule just like for monoradicals [31], followed by $\mathrm{H}$ atom abstraction before the collision complex dissociates (Scheme 8). The high reactivity of the SR group hinders some competing reactions, such as addition $-\mathrm{CO}_{2}$ and addition $-\mathrm{HCOOH}$. $\mathrm{NH}_{3}$ abstraction was observed only in the reactions of the biradical with Cys. Hence, this reaction likely involves the commonly observed $\mathrm{NH}_{2}$ abstraction, which in this case is followed by $\mathrm{H}$-atom abstraction from the $\mathrm{SH}$ group, before the complex dissociates. Indeed, a previous study of related monoradicals' reactions with amino acids demonstrated that $\mathrm{SH}$ in Cys is the preferred site for $\mathrm{H}$-atom abstraction by monoradicals [31].

\section{Dipeptides}

The gas-phase reactions of fifteen dipeptides with the aromatic $\sigma, \sigma$-biradical were also investigated (Table 2) (see Figure 2 for an example). The dipeptides can be separated into three categories based on the type of reactions they undergo. The first category includes the simple aliphatic dipeptides, Gly-Gly, Gly-Ala, Gly-Val, Gly-Leu, Gly-Ile, and Ala-Gly, the second category the aromatic dipeptides, Tyr-Leu, Phe-Val, Phe-Pro, Leu-Tyr, and Ala-Phe, and the third category the S-containing dipeptides, Cys-Gly, Met-Lys, Met-Gly, and Val-Met. These different categories are discussed in detail below.

\section{Gly-Gly, Gly-Ala, Gly-Val, Gly-Leu, Gly-Ile, and Ala-Gly}

Just as observed for the individual amino acids, dipeptides containing the simplest amino acids display different pathways upon reactions with aromatic $\sigma$-monoradicals and the aromatic $\sigma, \sigma$-biradical. While monoradicals (e.g., 3-dehydro- $N$-phenylpyridinium) react with aliphatic dipeptides (i.e., Gly-Gly, Gly-Ala, Gly-Val, and Gly-Ile) exclusively by $\mathrm{H}$-atom abstraction and $\mathrm{NH}_{2}$ abstraction (just as with the individual amino acids) [33], the biradical reacts with these dipeptides (and the individual amino acids) by several additional pathways. These include the pathways observed for the individual amino acids, i.e., $2 \mathrm{H}$-atom abstraction, $\mathrm{H}_{2} \mathrm{O}$ abstraction, addition - $\mathrm{HCOOH}$, addition $-\mathrm{CO}_{2}$, as well as formation of a stable adduct (Table 2), although from these, all except the $\mathrm{H}_{2} \mathrm{O}$ abstraction pathway are minor. In addition, a new major reaction pathway, addition/ C-terminal amino acid elimination (addition - $\mathrm{CO}$ $\mathrm{NHCHR}_{\mathrm{C}}$ ), was observed for the dipeptides. For exam-
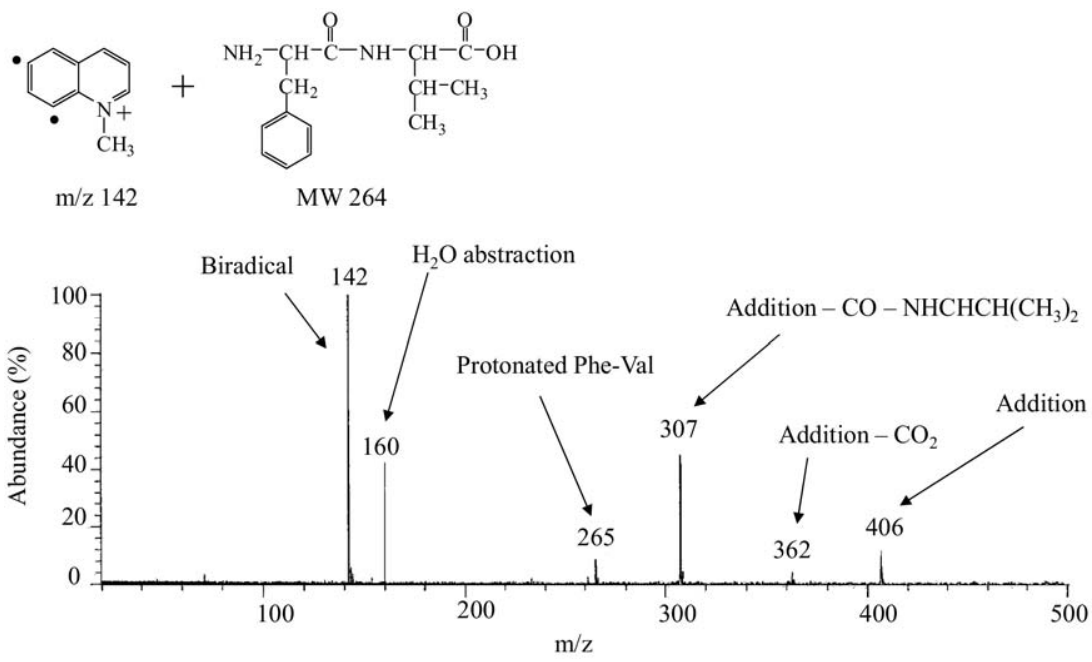

Figure 2. A mass spectrum measured for the reaction of the biradical $(\mathrm{m} / \mathrm{z} 142)$ with Phe-Val (MW 264) in FT-ICR. *Note: protonated Phe-Val is a secondary product. 

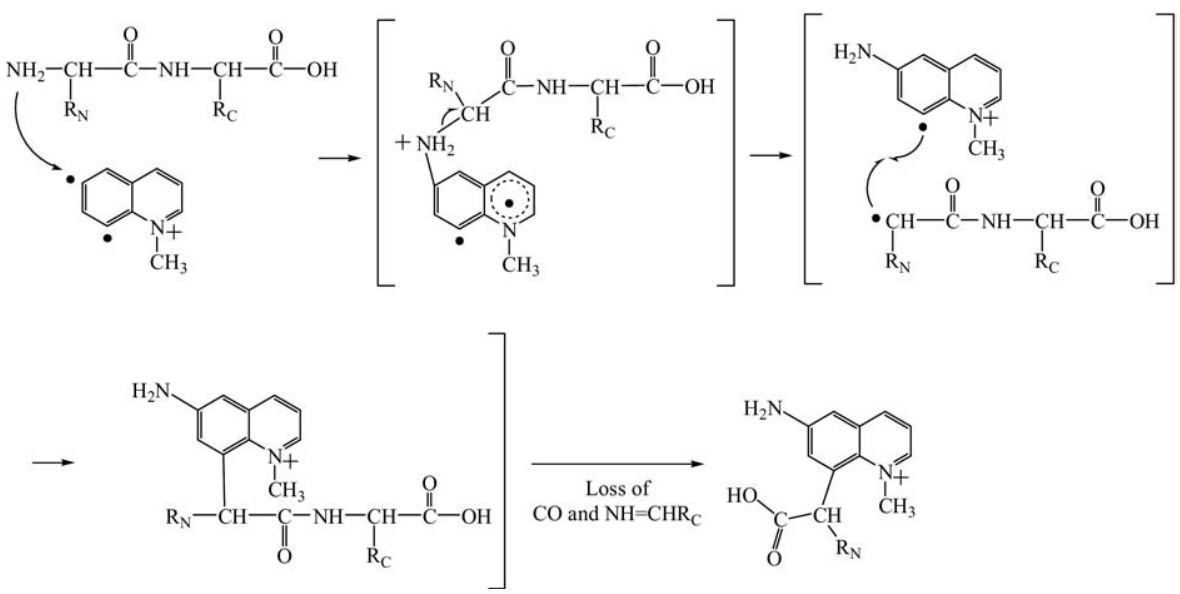

Scheme 9

ple, while a phenyl radical (e.g., 3-dehydro- $N$ phenylpyridinium) reacts with Gly-Ala by H-atom abstraction and $\mathrm{NH}_{2}$ abstraction [33], the $\sigma, \sigma$-biradical reacts with this peptide by $\mathrm{H}$-atom abstraction, $2 \mathrm{H}$ atom abstraction, $\mathrm{H}_{2} \mathrm{O}$ abstraction, addition - $\mathrm{CO}-$ $\mathrm{NHCHCH}_{3}$ (elimination of the C-terminal amino acid), addition - $\mathrm{CO}-\mathrm{NHCHCH}_{3}-\mathrm{CO}_{2}$, addition - $\mathrm{CO}-$ $\mathrm{NHCHCH}_{3}-\mathrm{H}_{2} \mathrm{O}$, addition $-\mathrm{HCOOH}$, addition $-\mathrm{CO}_{2}$ and formation of a stable adduct (Table 2).

A possible mechanism for the addition/C-terminal amino acid elimination is shown in Scheme 9. Similarly as for the reactions of the biradical with amino acids, the addition reactions of dipeptides are likely initiated by nucleophilic addition of $\mathrm{NH}_{2}$ (or an O-functionality) to the radical site at carbon 6 . The initially formed dipeptide adduct may undergo a homolytic $\mathrm{NH}_{2}-\alpha \mathrm{C}$ bond cleavage to yield two radicals. Exothermic radicalradical recombination leads to a hot addition product. Fragmentation of this addition product follows. Instead of major loss of $\mathrm{HCOOH}$ or $\mathrm{CO}_{2}$, as observed for the amino acids, the addition products formed from dipeptides undergo major loss of $\mathrm{CO}$ and $\mathrm{NHCHR}_{\mathrm{C}}$. This characteristic addition/C-terminal amino acid elimination (addition - $\mathrm{CO}-\mathrm{NHCHR}_{\mathrm{C}}$ ) demonstrates the significant influence of the peptide's exact amino acid sequence on its reactivity towards the biradical. For example, the biradical reacts with Gly-Ala and Ala-Gly to yield different products: addition - $\mathrm{CO}-\mathrm{NHCHCH}_{3}$ for GlyAla, and addition - $\mathrm{CO}-\mathrm{NHCH}_{2}$ for Ala-Gly (Table 2).

Some addition/C-terminal amino acid elimination products rearrange further and eliminate $\mathrm{HCOOH}$, or more rarely, $\mathrm{CO}_{2}$ or $\mathrm{H}_{2} \mathrm{O}$. For example, addition $-\mathrm{CO}-\mathrm{NHCH}_{2}$ - $\mathrm{HCOOH}$ and addition $-\mathrm{CO}-\mathrm{NHCH}_{2}-\mathrm{H}_{2} \mathrm{O}$ products were observed in the reaction of the biradical with Gly-Gly (Table 2); addition - $\mathrm{CO}-\mathrm{NHCHCH}_{3}-\mathrm{CO}_{2}$ and addition - $\mathrm{CO}-\mathrm{NHCHCH}_{3}-\mathrm{H}_{2} \mathrm{O}$ for Gly-Ala (Table 2), and addition - $\mathrm{CO}-\mathrm{NHCHCH}\left(\mathrm{CH}_{3}\right)_{2}-$ $\mathrm{HCOOH}$ for Gly-Val (Table 2). SORI-CAD of the isolated addition/C-terminal amino acid elimination product of Gly-Val was found to occur via the loss of $\mathrm{HCOOH}, \mathrm{CO}_{2}, \mathrm{H}_{2} \mathrm{O}$, or $\mathrm{C}_{2} \mathrm{H}_{2} \mathrm{O}_{2}$. That only loss of
$\mathrm{HCOOH}$ (addition - $\left.\mathrm{CO}-\mathrm{NHCHCH}\left(\mathrm{CH}_{3}\right)_{2}-\mathrm{HCOOH}\right)$ was observed in the reaction of the biradical with Gly-Val (Table 2) is likely due to particularly highenergy thresholds for the other reactions (i.e., loss of $\mathrm{CO}_{2}, \mathrm{H}_{2} \mathrm{O}$, and $\mathrm{C}_{2} \mathrm{H}_{2} \mathrm{O}_{2}$ ).

\section{Tyr-Leu, Phe-Val, Phe-Pro, Leu-Tyr, and Ala-Phe}

Aromatic dipeptides with the aromatic ring in the N-terminus (i.e., Tyr-Leu, Phe-Val, and Phe-Pro) display very similar pathways upon reaction with the biradical as aliphatic dipeptides. However, for aromatic dipeptides with the aromatic ring in the C-terminus (i.e., Leu-Tyr and Ala-Phe), one additional pathway, addition/N-terminal amino acid elimination (addition $\mathrm{CO}-\mathrm{NHCHR}_{\mathrm{N}}$ ), was observed. No such reaction was observed for the aliphatic dipeptides discussed above, or the aromatic dipeptides with the aromatic ring in the N-terminus. This characteristic addition/N-terminal amino acid elimination (addition $-\mathrm{CO}-\mathrm{NHCHR}_{\mathrm{N}}$ ) demonstrates that the position of the aromatic ring in dipeptides has an observable influence on the peptides' reactivity toward the biradical. For example, while addition $-\mathrm{CO}-\mathrm{NHCHR}_{\mathrm{N}}\left(\mathrm{R}_{\mathrm{N}}=\mathrm{CH}_{3}\right)$ occurs for Ala-Phe, the analogous reaction (addition - $\mathrm{CO}$ $\mathrm{NHCHR}_{\mathrm{N}} ; \mathrm{R}_{\mathrm{N}}=\mathrm{CH}_{2} \mathrm{C}_{6} \mathrm{H}_{5}$ ), does not take place for Phe-Val.

When considering the possible mechanism for the addition/N-terminal amino acid elimination reaction only observed for the reaction of the biradical with the aromatic dipeptides with the aromatic amino acid in the C-position, examination of the reactivity of related monoradicals proves useful. Previous experimental and theoretical studies of the reactions of charged phenyl monoradicals with aromatic amino acids demonstrated that monoradicals attack the ortho- or the para-position of the aromatic ring in amino acids, which can be followed by a homolytic $\mathrm{C} \alpha-\mathrm{C} \beta$ bond cleavage to form an aromatic side-chain abstraction product [32]. There is no reason to believe that this reaction does not occur also upon biradical attack. Hence, the addition/N- 


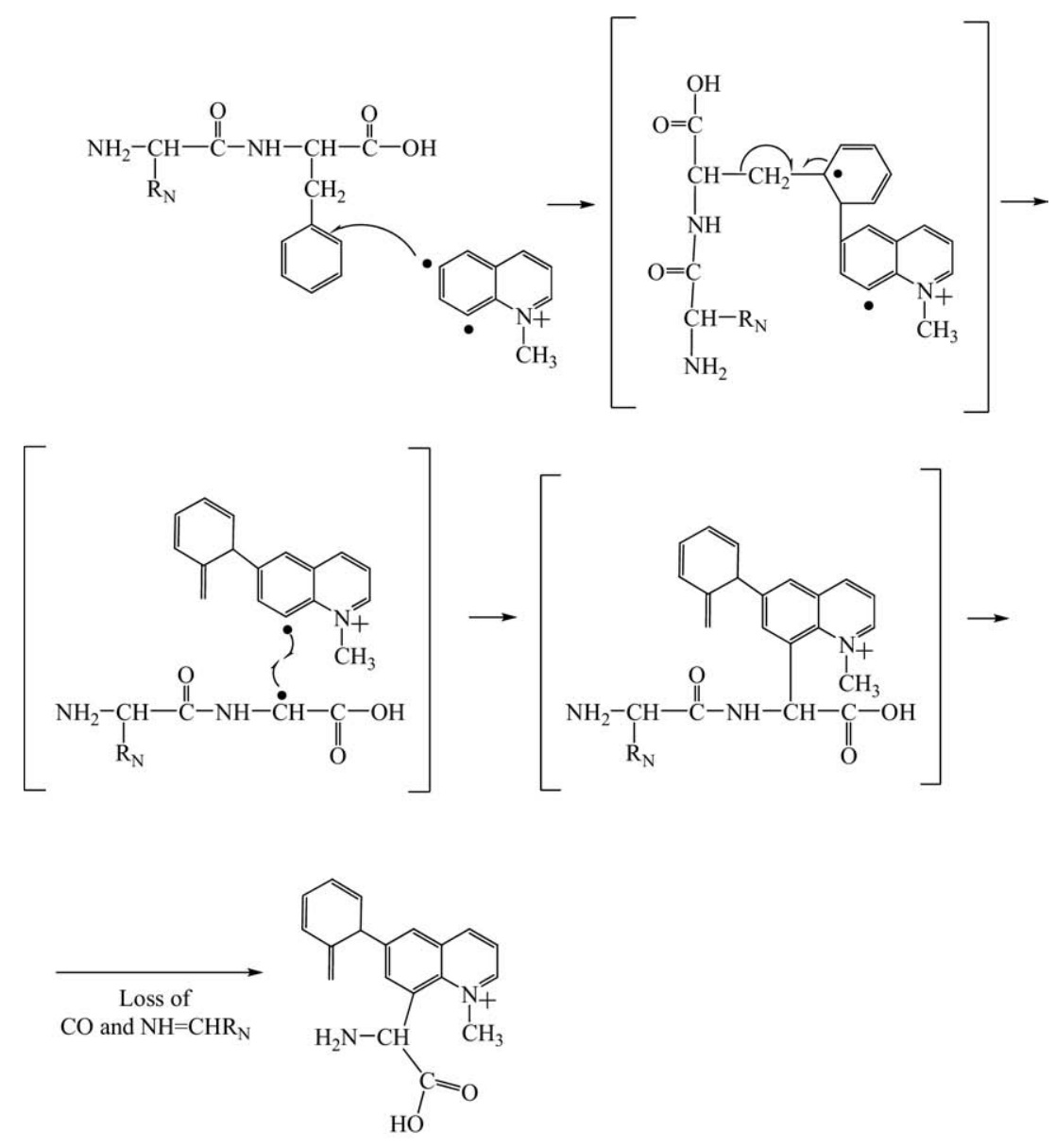

Scheme 10

terminal amino acid elimination is likely initiated by radical addition of the biradical to either the ortho- or the para-position of the aromatic ring in the C-terminal amino acid (ortho-addition is shown in Scheme $\mathbf{1 0}$ as an example), followed by a homolytic $\mathrm{C} \alpha-\mathrm{C} \beta$ bond cleav- age. Instead of dissociation of the product complex (as for monoradicals), the products in the complex react further by exothermic radical-radical recombination followed by elimination of the N-terminal amino acid as $\mathrm{CO}$ and $\mathrm{NHCHR}_{\mathrm{N}}$ (Scheme 10; similarly as $\mathrm{HCOOH}$

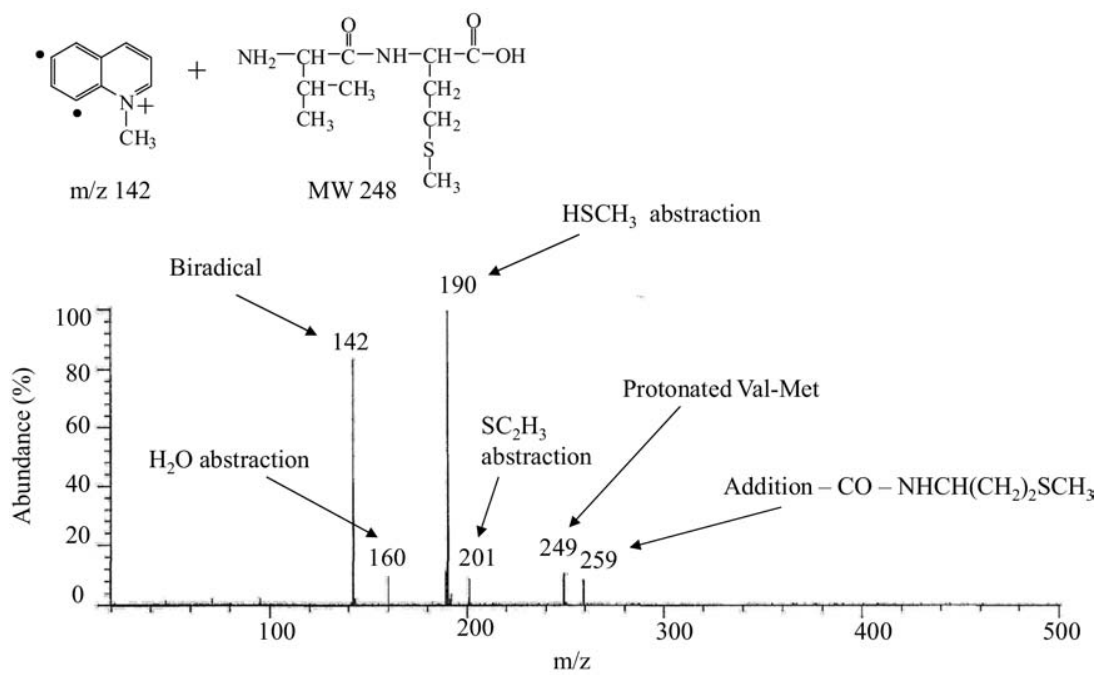

Figure 3. A mass spectrum measured for the reaction of the biradical $(\mathrm{m} / \mathrm{z} 142)$ with Val-Met (MW 264) in FT-ICR. *Note: protonated Val-Met is a secondary product. 
and $\mathrm{CO}_{2}$ are lost from the amino acids; Scheme 5). Note that several different pathways may lead to the formation of the stable adduct.

\section{Cys-Gly, Met-Lys, Met-Gly, and Val-Met}

Similar to S-containing amino acids (i.e., Cys and Met), the $\mathrm{S}-\mathrm{C}$ bond of S-containing dipeptides was found to be especially vulnerable to biradical attack. Indeed, while SR ( $\mathrm{R}=\mathrm{H}$ or $\mathrm{CH}_{3}$ ) abstraction dominates the reactions of related monoradicals (e.g., 3-dehydro- $N$ phenylpyridinium) with S-containing dipeptides (i.e., Cys-Gly, Met-Lys, Met-Gly, and Val-Met) (just as with the individual amino acids) [33], $\mathrm{HSR}\left(\mathrm{R}=\mathrm{H}\right.$ or $\left.\mathrm{CH}_{3}\right)$ abstraction dominates the reactions of the biradical with S-containing dipeptides. For example, the biradical reacts with Cys-Gly by predominant abstraction of a $\mathrm{SH}$ radical and a $\mathrm{H}$ atom to yield the $\mathrm{H}_{2} \mathrm{~S}$ abstraction product (Table 2) and with Val-Met by predominant abstraction of a $\mathrm{SCH}_{3}$ radical and a $\mathrm{H}$ atom to yield the
$\mathrm{HSCH}_{3}$ abstraction product (Figure 3, Table 2). The high reactivity of the SR group hinders some competing reactions, such as $\mathrm{H}$-atom abstraction, $2 \mathrm{H}$-atom abstraction, addition $-\mathrm{CO}_{2}$, addition $-\mathrm{HCOOH}$ and formation of a stable adduct. For example, no $\mathrm{H}$-atom abstraction, $2 \mathrm{H}$-atom abstraction, addition $-\mathrm{CO}_{2}$ nor addition $\mathrm{HCOOH}$ products were observed in the reaction of Met-Lys with the biradical (Table 2). Further, since Met-Lys has a C-terminal side-chain amino group available for biradical attack, it is not surprising that addition/N-terminal amino acid elimination (addition - $\mathrm{CO}$ $\mathrm{NHCHR}_{\mathrm{N}}\left(\mathrm{R}_{\mathrm{N}}=\mathrm{CH}_{2} \mathrm{CH}_{2} \mathrm{SCH}_{3}\right)$ was observed upon reaction of Met-Lys with the biradical (Scheme 11).

\section{Conclusions}

In conclusion, the combination of LIAD with FT-ICR mass spectrometry has been demonstrated to allow the detailed investigation of the reactivity of an aromatic
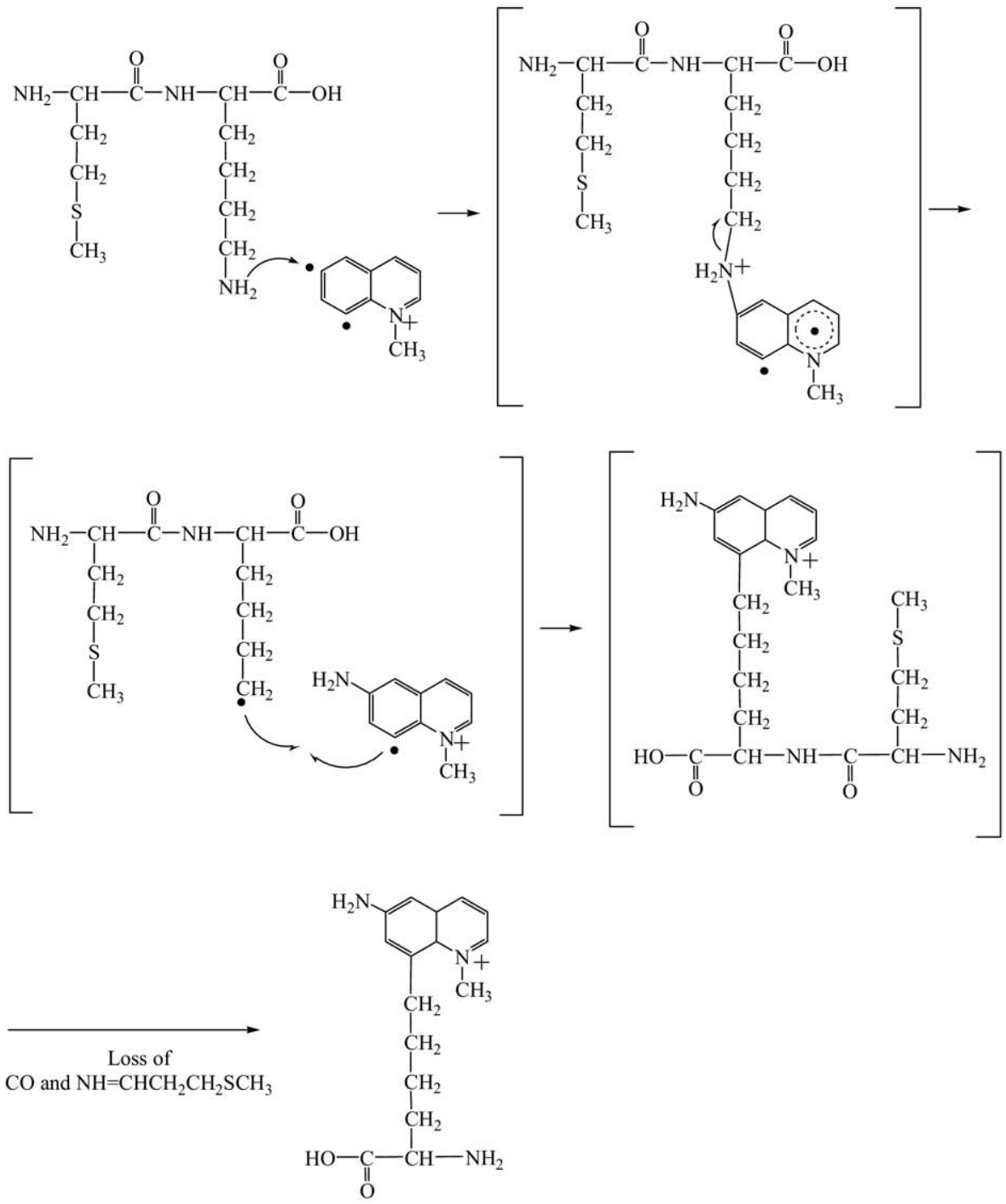

Scheme 11 
$\sigma, \sigma$-biradical (N-methyl-6,8-didehydroquinolinium) toward amino acids and dipeptides. While $\mathrm{H}$-atom abstraction and $\mathrm{NH}_{2}$ abstraction have been reported to dominate the reactions of related monoradicals (i.e., $N$-(2,3,5,6-tetrafluoro-4-dehydrophenyl)pyridinium and $N$ phenyl-3-dehydropyridinium) with aliphatic amino acids and small peptides containing these amino acids, several additional unprecedented reaction pathways were observed in the reactions of the biradical. For amino acids, these are $2 \mathrm{H}$-atom abstraction, $\mathrm{H}_{2} \mathrm{O}$ abstraction, addition $-\mathrm{CO}_{2}$, addition $-\mathrm{HCOOH}$ and formation of a stable adduct. For dipeptides, these pathways were also observed, in addition to one additional pathway, addition/C-terminal amino acid elimination (addition $-\mathrm{CO}-\mathrm{NHCHR}_{\mathrm{C}}$ ). Most of the biradi$\mathrm{cal}^{\prime}$ 's reactions are likely initiated in the same manner as the related monoradicals' reactions (with the exception of $\mathrm{H}_{2} \mathrm{O}$ abstraction), i.e., $\mathrm{H}$-atom abstraction, radical addition to an aromatic ring, or nucleophilic attack by an $\mathrm{NH}_{2}$ group in the biradical. $2 \mathrm{H}$-atom abstraction by the biradical from the peptides and addition of the biradical to an aromatic ring in C-terminal aromatic peptides (leading to $\mathrm{N}$-terminal amino acid elimination) likely occur by simple radical mechanisms. However, the reactions involving $\mathrm{C}-\mathrm{N}$ and $\mathrm{C}-\mathrm{O}$ bond formation are probably initiated by nucleophilic attack of a N- (as for monoradicals) or O-atom (not observed for monoradicals) of the amino acid or peptide at the radical site at carbon- 6 in the biradical. This site appears to be the most reactive site in the biradical, no matter what the mechanism of the reaction. After the reaction of the first radical site (C-6), the unquenched radical site at C-8 reacts to give products not observed for analogous monoradicals.

The biradical reacts with the aromatic dipeptides that contain the aromatic amino acid in the N-terminus similarly as with aliphatic dipeptides. However, for those aromatic dipeptides with the aromatic amino acid in the C-terminus (i.e., Leu-Tyr and Ala-Phe), one additional pathway, addition/N-terminal amino acid elimination (addition - $\mathrm{CO}-\mathrm{NHCHR}_{\mathrm{N}}$ ), was observed. This reaction is likely initiated by radical addition of the biradical to the aromatic group in the C-terminus (Scheme 9). Addition to aromatic rings in amino acids and peptides has been found to lead to side-chain abstraction for monoradicals. However, for the biradical, reactions at the unquenched radical site eventually lead to elimination of the N-terminal amino acid.

In addition, similar to monoradicals' attack, the C-S bond in amino acids and dipeptides was found to be especially susceptible to biradical attack. While SR $(\mathrm{R}=$ $\mathrm{H}$ or $\mathrm{CH}_{3}$ ) abstraction has been reported to dominate the reactions of monoradicals with S-containing amino acids $^{5 a}$ and dipeptides, an additional reaction pathway, HSR abstraction, dominates the reactions of the biradical with S-containing amino acids and dipeptides. This reaction is likely initiated by SR abstraction by the radical site at C-6 in the biradical (just like monoradi- cals), followed by $\mathrm{H}$-atom abstraction by the unquenched radical site at C-8.

Previous gas-phase studies on positively charged phenyl radicals revealed reactivity toward protein components that is similar to that of neutral hydroxyl and phenyl radicals in solution. For example, both a condensed-phase neutral phenyl radical (the 4dehydrobenzoic acid) and gas-phase positively charged phenyl radicals (e.g., $N$-(3-dehydrophenyl)pyridinium) react with $\alpha, \alpha$-dideuterioglycine by abstraction of a D-atom from the $\alpha$-position. Therefore, exploration of the gas-phase reactivity of carbon-centered aromatic biradicals with protein components may provide information relevant to condensed phase studies. Indeed, it was found here that a gas-phase biradical can damage dipeptides by abstraction of $\mathrm{H}$-atoms similarly as found in condensed phase studies. For example, a synthetic enediyne has been found to abstract a D-atom from the $\alpha$ C-position of deuterated glycine mimics, likely via a biradical intermediate (Scheme 1).

\section{Acknowledgments}

The authors gratefully acknowledge the National Institutes of Health for providing financial support for this work.

\section{References}

1. Davies, M. J.; Dea, R. T. Radical-Mediated Protein Oxidation: from Chemistry to Medicine; Oxford University Press: Oxford, 1997; pp 1-443.

2. Pratviel, G.; Bernadou, J.; Meunier, B. Carbon-Hydrogen Bonds of DNA Sugar Units as Targets for Chemical Nucleases and Drugs. Angew. Chem. Int. Ed. Engl. 1995, 34, 746-769.

3. Griffiths, J.; Murphy, J. A. Cleavage of DNA Resulting from Exposure to Phenyl Radicals. J. Chem. Soc. Chem. Commun. 1992, 1, 24-26.

4. Davies, J. M.; Fu, S.; Wang, H.; Dean, R. T. Stable Markers of Oxidant Damage to Proteins and Their Application in the Study of Human Disease. Free Radic. Biol. Med. 1999, 27, 1151-1163.

5. Dean, T. R.; Fu, S.; Stocker, R.; Davis, J. M. Biochemistry and Pathology of Radical-mediated Protein Oxidation. Biochem. J. 1997, 324, 1-18.

6. Hawkins, C. L.; Davies, M. J. Generation and Propagation of Radical Reactions on Proteins. Biochim. Biophys. Acta Bioenegentics 2001, 1504 , 196-219.

7. Garrison, M. W. Radiation-Induced Reactions of Amino Acids and Peptides. Radiat. Res. Rev. 1972, 3, 305-326.

8. Easton, J. C. Free-Radical Reactions in the Synthesis of $\alpha$-Amino Acids and Derivatives. Chem. Rev. 1997, 97, 53-82.

9. Davies, J. K. Protein Damage and Degradation by Oxygen Radicals. IV. Degradation of Denatured Protein. I. Biol. Chem. 1987, 262, 9914-9920.

10. Goshe, B. M.; Chen, H. Y.; Anderson, E. V. Identification of the Sites of Hydroxyl Radical Reaction with Peptides by Hydrogen/Deuterium Exchange: Prevalence of Reactions with the Side Chains. Biochemistry 2000, 39, 1761-1770.

11. Buxton, G. V.; Greenstock, C. L.; Helman, W. P. Ross, A. B. Critical Review of Rate Constants for Reactions of Hydrated Electrons, Hydrogen Atoms, and Hydroxyl Radicals $\left(\cdot \mathrm{OH} / \cdot \mathrm{O}^{-}\right)$in Aqueous Solution. J. Phys. Chem. Ref. Data 1988, 17, 513-887.

12. Deterding, L. J.; Barr, D. P.; Mason, R. P.; Tomer, K. B. Characterization of Cytochrome $c$ Free Radical Reactions with Peptides by Mass Spectrometry. J. Biol. Chem. 1998, 273, 12863-12869.

13. Bonifačić, M.; Štefanić, I.; Hug, G. L.; Armstrong, D. A.; Asmus, K.-D. Glycine Decarboxylation: The Free Radical Mechanism. J. Am. Chem. Soc. 1998, 120, 9930-9940.

14. Braslau, R.; Anderson, M. O. Abstraction of Deuterium from Dideuteroglycine by Aryl Radical: A Model for 1,4-Benzene Diradical Reactions with Proteins. Tetrahedron Lett. 1998, 39, 4227-4230.

15. Nicolaou, K. C.; Dai, W.-M. Chemistry and Biology of the Enediyne Anticancer Antibiotics. Angew. Chem. Int. Ed. Engl. 1991, 30, 1387-1416.

16. Nicolaou, K. C.; Dai, W. M.; Tsay, S.-C.; Estevez, V. A.; Wrasidlo, W. Designed Enediynes: A New Class of DNA-Cleaving Molecules with Potent and Selective Anticancer Activity. Science 1992, 256, 1172-1178.

17. Pogozelski, W. K.; Tullius, T. D. Oxidative Strand Scission of Nucleic Acids: Routes Initiated by Hydrogen Abstraction from the Sugar Moiety. Chem. Rev. 1998, 98, 1089-1108. 
18. Wenk, H. H.; Winkler, M.; Sander, W. One Century of Aryne Chemistry. Angew. Chem. Int. Ed. Engl. 2003, 42, 502-528.

19. Magnus, P.; Eisenbeis, S. A.; Fairhurst, R. A.; Magnus, N. A.; Parry, D. Synthetic and Mechanistic Studies on the Azabicyclo[7.3.1]Enediyne Core and Naphtho[2,3-h]Quinoline Portions of Dynemicin A. J. Am. Chem. Soc. 1997, 119, 5591-5605.

20. Grissom, J. W.; Gunawardena, G. U.; Klingberg, D.; Huang, D. H. The Chemistry of Enediynes, Enyne Allenes, and Related Compounds. Tetrahedron 1996, 52, 6453-6518.

21. Zein, N.; Casazza, A. M.; Doyle, T. W.; Nadler, S. G. Selective Proteolytic Activity of the Antitumor Agent Kedarcidin. Proc. Natl. Acad. Sci. U.S.A. 1993, 90, 8009-8012.

22. Zein, N.; Reiss, P.; Bernatowicz, M.; Bolgar, M. The Proteolytic Specificity of the Natural Enediyne-Containing Chromoproteins is Unique to Each Chromoprotein. Chem. Biol. 1995, 2, 451-455.

23. Zein, N.; Schroeder, D. R. Advances in DNA Sequence Specific Agents Vol. III; Jones, G. B., Ed., JAI Press: Greenwich, 1998; p. 201.

24. Zein, N.; Solomon, W.; Casazza, A. M.; Kadow, J. F.; Krishnan, B. S.; Tun, M. M.; Vyas, D. M.; Doyle, T. W. Protein Damage Caused by a Synthetic Enediyne Core. Bioorg. Med. Chem. Lett. 1993, 3, 1351-1356.

25. Jones, G. B.; Plourde, G. W.; Wright, J. M. Understanding EnediyneProtein Interactions: Diyl Atom Transfer Results in Generation of Aminoacyl Radicals. Org. Lett. 2000, 2, 811-813.

26. Hawkins, C. L.; Davies, M. J. EPR Studies on the Selectivity of Hydroxyl Radical Attack on Amino Acids and Peptides. J. Chem. Soc. Perkin Trans. 2 1998, 2617-2622.

27. Nukuna, B. N.; Goshe, M. B.; Anderson, V. E. Sites of Hydroxyl Radical Reaction with Amino Acids Identified by H-2 NMR Detection of Induced H-1/H-2 Exchange. J. Am. Chem. Soc. 2001, 123, 1208-1214.

28. Wenthold, P. G.; Paulino, J. A.; Squires, R. R. The Absolute Heats of Formation of $\mathrm{o}^{-}, \mathrm{m}-$, and p-Benzyne. J. Am. Chem. Soc. 1991, 113, 7414-7415.

29. Davico, G.; Bierbaum, V. M.; Depuy, C. H.; Ellison, G. B.; Squires, R. R. The C-H Bond Energy of Benzene. J. Am. Chem. Soc. 1995, 117, 2590-2599.

30. Sun, Q.; Nelson, H.; Ly, T.; Stoltz, B. M.; Julian, R. R. Side Chain Chemistry Mediates Backbone Fragmentation in Hydrogen Deficient Peptide Radicals. J. Proteome Res. 2009, 8, 958-966.

31. Huang, Y.; Guler L.; Heidbrink, J.; Kenttämaa, H. I. Reactions of Charged Phenyl Radicals with Aliphatic Amino Acids in the Gas Phase. J. Am. Chem. Soc. 2005, 127, 3973-3978.

32. Huang, Y.; Kenttämaa, H. I. Theoretical and Experimental Investigations on the Reactions of Positively Charged Phenyl Radicals with Aromatic Amino Acids. J. Am. Chem. Soc. 2005, 127, 7952-7960.

33. Li, S.; Fu, M.; Habicht, S. C.; Pates, G. O.; Nash, J. J.; Kenttämaa, H. I. Phenyl Radical-Induced Damage to Dipeptides. J. Org. Chem. 2009, 74, 7724-7732.

34. Shea, R. C.; Campbell, J. L.; Petzold, C. J.; Li, S.; Aaserud, D. J.; Kenttämaa, H. I. Characterization of Laser-Induced Acoustic Desorption Coupled with a Fourier Transform Ion Cyclotron Resonance Mass Spectrometer. Anal. Chem. 2006, 78, 6133-6139.

35. Liu, J.; Petzold, C. J.; Ramirez-Arizmendi, L. E.; Perez, J.; Kenttämaa, H. I. Phenyl Radicals React with Dinucleoside Phosphates by Addition to Purine Bases and H-Atom Abstraction from a Sugar Moiety. J. Am. Soc. Chem. 2005, 127, 12758-12759.

36. Duan, P.; Fu, M.; Pinkston, D. S.; Habicht, S. C. Kenttämaa, I. Gas-Phase Reactions of $\mathrm{ClMn}\left(\mathrm{H}_{2} \mathrm{O}\right)^{+}$with Polar and Nonpolar Hydrocarbons in a Mass Spectrometer. J. Am. Soc. Chem. 2007, 129, 9266-9267.

37. Duan, P.; Qian, K.; Habicht, S. C.; Pinkston, D. S.; Fu, M.; Kenttämaa, H. I. Analysis of Base Oil Fractions by ClMn $\left(\mathrm{H}_{2} \mathrm{O}\right)^{+}$Chemical Ionization Combined with Laser-induced Acoustic Desorption/Fourier Transform
Ion Cyclotron Resonance Mass Spectrometry. Anal. Chem. 2008, 80, 1847-1853.

38. Perez, J.; Ramirez-Arizmendi, L. E.; Petzold, C. N.; Guler, L. P.; Nelson, E. D.; Kenttämaa, H. I. Laser-induced Acoustic Desorption/Chemical Ionization in Fourier-transform Ion Cyclotron Resonance Mass Spectrometry. Int. J. Mass Spectrom. 2000, 198, 173-188.

39. Yang, L.; Nash, J. J.; Yurkovich, M. J.; Jin, Z.; Vinueza, N. R. ; Kenttämaa, H. I. Gas-Phase Reactivity of Aromatic $\sigma, \sigma$-Biradicals toward Dinucleoside Phosphates. Org. Lett. 2008, 10, 1889-1892.

40. Adeuya, A.; Yang, L. ; Amegayibor, F. S.; Nash, J. J.; Kenttämaa, H. I. Reactivity of Aromatic $\sigma, \sigma$-Biradicals Toward Riboses. J. Am. Soc. Mass Spectrom. 2006, 17, 1325-1334.

41. Nash, J. J.; Kenttämaa, H. I.; Cramer, C. J. Quantum Chemical Characterization of the Structures, Thermochemical Properties, and SingletTriplet Splittings of Didehydroquinolinium and Didehydroisoquinolinium Ions. J. Phys. Chem. A 2005, 109, 10348-10356.

42. Nash, J. J.; Kenttämaa, H. I.; Cramer, C. J. Quantum Chemical Characterization of the Vertical Electron Affinities of Didehydroquinolinium and Didehydroisoquinolinium Cations. J. Phys. Chem. A 2006, 110, 10309-10315.

43. Nash, J. J.; Nizzi, K.; Adeuya, A.; Yurkovich, M. J.; Cramer, C. J. Kenttämaa, H. I. Demonstration of Tunable Reactivity for metaBenzynes. J. Am. Chem. Soc. 2005, 127, 5760-5761.

44. Campbell, J. L.; Fiddler, M. N.; Crawford, K. E.; Gqamana, P. P. Kenttämaa, H. I. Analysis of Polyethylene by Using Cyclopentadienyl Cobalt Chemical Ionization Combined with Laser-Induced Acoustic Desorption/Fourier Transform Ion Cyclotron Resonance Mass Spectrometry. Anal. Chem. 2005, 77, 4020-4026.

45. Crawford, K. E. Campbell, J. L.; Fiddler, M. N.; Duan P.; Qian, K. Gorbaty, M. L.; Kenttämaa, H. I. Laser-Induced Acoustic Desorption/ Fourier Transform Ion Cyclotron Resonance Mass Spectrometry for Petroleum Distillate Analysis. Anal. Chem. 2005, 77, 7916-7923.

46. Serban, A.; Patent, ICI, US 3930837, 1976.

47. Ohta, A.; Kurihara, T.; Ichimura, H.; Watanabe, T. Nitration of Mononitroquinolines. Chem. Pharm. Bull. 1979, 27, 2627-2635.

48. Rieche, A.; Schmitz, E.; Dietrich, P. Stickstoffhaltige Peroxyde, III Peroxyde aus stickstoffhaltigen Pseudobasen. Eine Methode zur Identifizierung von Alkylhydroperoxyden. Chem. Ber. 2006, 92, 2239-2252.

49. Guan, S.; Kim, H. S.; Marshall, A. G.; Wahl, M. C.; Wood, T. D.; Xiang, $X$. Shrink-Wrapping an Ion Cloud for High-performance Fourier Transform Ion Cyclotron Resonance Mass Spectrometry. Chem. Rev. 1994, 94, 2161-2182.

50. Gauthier, J. W.; Trautman, T. R.; Jacbson, D. B. Sustained Off-Resonance Irradiation for Collision-activated Dissociation Involving Fourier Transform Mass Spectrometry. Collision-Activated Dissociation Technique that Emulates Infrared Multiphoton Dissociation. Anal. Chim. Acta 1991, $246,211-225$.

51. Chen, L.; Wang, T. C. L.; Ricca, T. L.; Marshall, A. G. Phase-Modulated Stored Waveform Inverse Fourier Transform Excitation for Trapped Ion Mass Spectrometry. Anal. Chem. 1987, 59, 449-454.

52. Marshall, A. G.; Wang, T. C. L.; Ricca, T. L. Tailored Excitation for Fourier transform ion cyclotron mass spectrometry. J. Am. Chem. Soc. 1985, 107, 7893-7897.

53. Petzold, C. J.; Ramirez-Arizmendi, L. E.; Heidbrink, J. L.; Kenttämaa H. I. Gas-Phase Reactions of Charged Phenyl Radicals with Neutral Biomolecules Evaporated by Laser-induced Acoustic Desorption. J. Am. Soc. Mass Spectrom. 2002, 13, 192-194.

54. Yu, D.; Rauk, A.; Yu, D.; Armstrong, D. A. Radicals and Ions of Glycine: $\mathrm{An} \mathrm{Ab}$ Initio Study of the Structures and Gas-Phase Thermochemistry. J. Am. Chem. Soc. 1995, 117, 1789-1796. 